\title{
High temporal resolution estimates of columnar aerosol microphysical parameters from spectrum of aerosol optical depth by linear estimation: application to long-term AERONET and star-photometry measurements
}

\author{
D. Pérez-Ramírez ${ }^{1,2,3}$, I. Veselovskii ${ }^{4}$, D. N. Whiteman ${ }^{1}$, A. Suvorina ${ }^{4}$, M. Korenskiy ${ }^{4}$, A. Kolgotin ${ }^{4}$, B. Holben ${ }^{6}$, \\ O. Dubovik ${ }^{5}$, A. Siniuk ${ }^{6,7}$, and L. Alados-Arboledas ${ }^{3,8}$ \\ ${ }^{1}$ Mesoscale Atmospheric Processes Laboratory, NASA Goddard Space Flight Center, 20771, Greenbelt, Maryland, USA \\ ${ }^{2}$ Universities Space Research Association, 21044, Columbia, Maryland, USA \\ ${ }^{3}$ Applied Physics Department, University of Granada, Avd. Fuentenueva s/n, 18071 Granada, Spain \\ ${ }^{4}$ Physics Instrumentation Center of General Physics Institute, Troitsk, Moscow Region, 142190, Russia \\ ${ }^{5}$ Laboratoire d'Optique Atmospherique, CNRS Universite de Lille 1, Bat P5 Cite scientifique, \\ 59655 Villeneuve d'Ascq CEDEX, France \\ ${ }^{6}$ Biospheric Sciences Branch, NASA Goddard Space Flight Center, 20771, Greenbelt, Maryland, USA \\ ${ }^{7}$ Sigma Space Corporation, 20771, Lanham, Maryland, USA \\ ${ }^{8}$ Andalusian Institute for Earth System Research (IISTA), Av. del Mediterráneo s/n, 18006 Granada, Spain \\ Correspondence to: D. Pérez-Ramírez (daniel.perezramirez@nasa.gov, dperez@ugr.es)
}

Received: 16 December 2014 - Published in Atmos. Meas. Tech. Discuss.: 4 March 2015

Revised: 10 July 2015 - Accepted: 10 July 2015 - Published: 5 August 2015

\begin{abstract}
This work deals with the applicability of the linear estimation technique (LE) to invert spectral measurements of aerosol optical depth (AOD) provided by AERONET CIMEL sun photometers. The inversion of particle properties using only direct-sun AODs allows the evaluation of parameters such as effective radius $\left(r_{\text {eff }}\right)$ and columnar volume aerosol content $(V)$ with significantly better temporal resolution than the operational AERONET algorithm which requires both direct sun and sky radiance measurements. Sensitivity studies performed demonstrate that the constraints on the range of the inversion are very important to minimize the uncertainties, and therefore estimates of $r_{\text {eff }}$ can be obtained with uncertainties less than $30 \%$ and of $V$ with uncertainties below $40 \%$. The LE technique is applied to data acquired at five AERONET sites influenced by different aerosol types and the retrievals are compared with the results of the operational AERONET code. Good agreement between the two techniques is obtained when the fine mode predominates, while for coarse mode cases the LE results systematically underestimate both $r_{\text {eff }}$ and $V$. The highest differences are found for cases where no mode predominates. To minimize
\end{abstract}

these biases, correction functions are developed using the multi-year database of observations at selected sites, where the AERONET retrieval is used as the reference. The derived corrections are tested using data from 18 other AERONET stations offering a range of aerosol types. After correction, the LE retrievals provide better agreement with AERONET for all the sites considered. Finally, the LE approach developed here is applied to AERONET and star-photometry measurements in the city of Granada (Spain) to obtain dayto-night time evolution of columnar aerosol microphysical properties.

\section{Introduction}

In the last few decades there has been a great advance in the evaluation of aerosol properties worldwide through remote sensing techniques. This has been partly due to the technological developments in passive remote sensing involving both satellite and ground-based measurements. An 
example of such a development is the use of sun photometry to acquire direct-sun irradiance and sky measurements in an automatic manner. In this framework, numerous international networks have been established (e.g. SKYNET (http: //atmos.cr.chiba-u.ac.jp/), AEROCAN (http://aerocanonline. com/), RIMA (http://www.rima.uva.es/)). The most global of them, though, is AERONET, which includes more than 400 stations around the world (Holben et al., 1998). From directsun-irradiance measurements, AERONET provides information about columnar aerosol optical properties such as spectral aerosol optical depth $(\operatorname{AOD}(\lambda))$ and the Ångström exponent $(\alpha(\lambda))$.

The inversion of sun-photometry optical data to obtain particle microphysical properties has been done through numerous approaches (e.g. King et al., 1978; Nakajima et al., 1996; Dubovik and King, 2000; Olmo et al., 2008). Currently, the AERONET inversion algorithm makes use of direct-sun and sky radiance measurements (Dubovik et al., 2002a, 2006). However, this algorithm requires completely cloudless skies and large solar zenith angles (typically larger than $45^{\circ}$ are desirable for achieving high accuracy retrievals; Dubovik et al., 2000). Thus, generally $\sim 8$ inversions per day are possible. This is to be compared with the direct measurements of $\operatorname{AOD}(\lambda)$ which are available four or more times per hour. Therefore, the desire for high temporal-resolution aerosol microphysical properties encourages the investigation of inversion methods that rely only on $\operatorname{AOD}(\lambda)$. Moreover, there are other simple sun-photometer designs that only obtain $\operatorname{AOD}(\lambda)$ and could potentially make use of such a technique. These other instruments include the following: MICTROTOPS used in the Maritime Aerosol Network (Smirnov et al., 2009, 2011), Precision Filter Radiometers (PFRs) (http: //www.pmodwrc.ch/worcc/) or Multifilter Rotating Shadowband Radiometers (MFRSRs) (e.g. Alexandrov et al., 2008). Another motivation for developing such inversions algorithms is the development of star photometers (Herber et al., 2002; Perez-Ramirez et al., 2008a, 2012a; Baibakov et al., 2015) and moon photometers (Esposito et al., 1998; Berkoff et al., 2011; Barreto et al., 2013) that can be used to fill the night-time gaps in the aerosol time series. However, the information content of retrievals based on $\operatorname{AOD}(\lambda)$ only is lower compared to those based on combined direct-sun and sky-radiance measurements. In particular, the particle refractive index cannot be retrieved with AOD information only. Thus, a more limited number of particle parameters can be retrieved using only $\operatorname{AOD}(\lambda)$ as input data. Still, the retrieval of effective radius $\left(r_{\text {eff }}\right)$ and columnar volume aerosol content $(V)$ from AODs as inputs would bring significant advances due to the high temporal resolution of the retrievals and their possible application to a number of simple instruments.

The problem of particle microphysical parameter estimation from a small number of measurements has been actively discussed in the last two decades in the context of multi-wavelength lidar measurements where typically only three backscattering and two extinction coefficients are available (e.g. Müller et al., 1999a, b; Veselovskii et al., 2002). The inversion of lidar measurements is usually performed by use of the regularization technique (Müller et al., 1999a, b; Veselovskii et al., 2002, 2004; Ansman and Müller, 2005). An alternate approach based on the expansion of the particle size distribution in terms of the kernel functions has also been studied (Twomey, 1977; Thomason and Osborn, 1992; Donovan and Carswell, 1997; Veselovskii et al., 2012, 2013; De Graaf et al., 2013). Hereafter we call this alternate approach the linear estimation (LE) technique because the particle bulk properties are represented by a linear combination of input optical data. The application of the LE technique to lidar observations has demonstrated that the algorithm is robust and fast compared to other techniques such as regularization (Veselovskii et al., 2012).

The work presented here deals with the use of the LE technique to invert AODs from AERONET sun-photometer measurements to retrieve aerosol microphysical information. The first results of the application of LE to AODs measured by AERONET and PFR were reported recently by Kazadzis et al. (2014). The results were presented for one site (Athens, Greece) and demonstrated reasonable agreement with the operational AERONET algorithm. Systematic discrepancies between the two approaches were observed, however, and more studies are called for. The current paper considers representative AERONET sites characterized by different aerosol types such as industrial pollution, biomass burning, dust, or mixtures of these types. Taking the operational AERONET retrievals as the reference, correction functions for $r_{\text {eff }}$ and $V$ are developed. The possibility of AOD inversions by LE is also studied using star photometry measurements in order to fill the night-time gaps in sun photometry based results.

This paper is organized as follows: Sect. 2 describes the LE technique and the constraints used, while Sect. 3 deals with a sensitivity study involving the input parameters. In Sect. 4, the LE inversion technique is applied to AERONET at reference sites and correction functions are obtained. This section also shows day-to-night time evolution of columnar aerosol microphysical properties using AERONET data and star-photometry measurements in the city of Granada (Spain). Finally, in Sect. 5 the main conclusions are discussed.

\section{Algorithm description}

\subsection{Theoretical background}

The aerosol optical depth at wavelength " $\lambda$ ” $(\operatorname{AOD}(\lambda))$ is related to the columnar particle volume size distribution $v(r)$ (i.e., the volume of particles per unit area per unit radius interval in the vertical atmospheric column) via the integral 
equation:

$\operatorname{AOD}_{i}(\lambda)=\int_{r_{\min }}^{r_{\max }} \mathbf{K}_{i}\left(r, m, \lambda_{i}\right) \boldsymbol{v}(r) \mathrm{d} r \quad i=1, \ldots, N$,

where $\mathbf{K}(m, r, \lambda)$ are the kernels depending on the particle radius $r \in\left[r_{\min }, r_{\text {max }}\right]$, complex refractive index $m=m_{R}+\operatorname{im}_{i}$ and wavelength " $\lambda$ ", and " $N$ " is the number of wavelengths considered. In this study the kernels are computed from Mie theory, thereby implying that we treat particles as spheres. Accounting for effects of non-sphericity is not essential when only AODs are considered in the inversion (Mischenko et al., 1997). For a discretized treatment, Eq. (1) can be rewritten in a vector-matrix form as follows:

$g=\mathbf{K} v$,

where $\boldsymbol{v}$ is the column vector with elements $\boldsymbol{v}_{k}$ corresponding to the particle volume inside radii interval $\left[r_{k}, r_{k+1}\right]$ and $\mathbf{K}$ is the matrix containing the discretized kernels as rows. Vector $\boldsymbol{g}$ contains input $\operatorname{AOD}(\lambda)$ values. In the LE approach, the particle size distribution (PSD) is approximated by a superposition of the kernel functions permitting an estimate of columnar volume aerosol content as follows (Veselovskii et al., 2012):

$\boldsymbol{v}=\mathbf{K}^{T}\left(\mathbf{K K}^{T}\right)^{-1} \boldsymbol{g}$.

In a similar way, the surface and number contributions can be calculated. In LE, if there is one or several aerosol characteristics $\boldsymbol{p}_{i}\left(i=1, \ldots, N_{p}\right)$ to be estimated using measurements of AODs, the dependence on the size distribution can be described as follows:

$\boldsymbol{p}=\mathbf{P} \boldsymbol{v}$,

where the elements $\boldsymbol{p}_{i}$ of vector $\boldsymbol{p}$ are the unmeasured aerosol characteristics, and $\mathbf{P}$ contains the weight coefficients for different integral properties as rows (Donovan and Carswell, 1997). For example, for volume $(i=1) \mathbf{P}_{1 k}=1$, for surface $(i=2) \mathbf{P}_{2 k}=3 / r_{k}$ and for number density $(i=$ 3) $\mathbf{P}_{3 k}=3 / 4 \pi r_{k}^{3}$. The linear estimation algorithm for inverting AODs used here is based on the heritage of that developed for inverting multi-wavelength lidar data (Veselovskii et al., 2012, 2013, 2015). This algorithm is characterized by the search for a family of solutions determined by use of the discrepancy $(\rho)$ defined as the difference between the input data $\operatorname{AOD}(\lambda)$ and the data calculated from the solutions obtained. The averaging of this family of solutions stabilizes the inversion, as the final solution is the mean of a large number of individual solutions near the minimum of discrepancy. Moreover, the inversion is run for an established inversion window that depends on particle type predominance. The use of such constraint is studied below. A detailed description of the LE approach is given in Veselovskii et al. (2012).

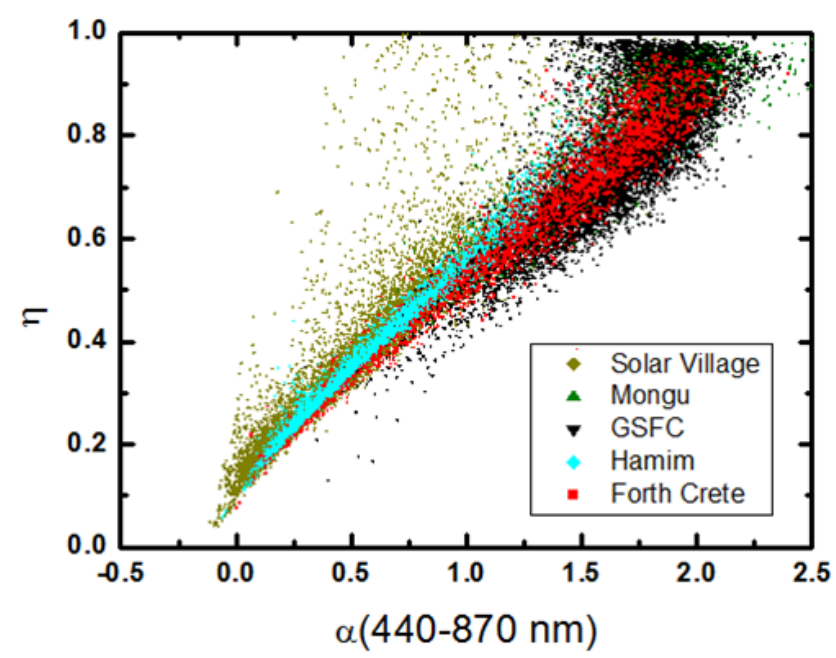

Figure 1. Fine mode fraction to aerosol optical depth $(\eta)$ as function of Ångström parameter $(\alpha(440-870))$.

\subsection{Constraints used in the inversion}

The sun-photometer CIMEL is the standard instrument of the AERONET network. It is able to measure sun direct irradiance and separate it spectrally by using interference filters centered at 340, 380, 440, 500, 670, 870 and $1020 \mathrm{~nm}$. The instruments are calibrated by AERONET and the final errors in $\operatorname{AOD}(\lambda)$ are approximately \pm 0.02 for $\lambda<400 \mathrm{~nm}$ and of \pm 0.01 for $\lambda>400 \mathrm{~nm}$ (Holben et al., 1998). All of the AERONET data used in this study were Level 2.0 (cloudscreened and quality-assured). More details can be found in Holben et al. (1998) and Smirnov et al. (2000). From the $\operatorname{AOD}(\lambda)$ measurements, the spectral deconvolution algorithm (SDA) (O'Neill et al., 2001a, b, 2003) provides also the fraction of the total optical depth that is due to the fine mode only $(\eta)$ at the reference wavelength of $500 \mathrm{~nm}$.

Figure 1 represents $\eta$ vs. the Angström exponent $\alpha(440$ 870) using the data of selected AERONET stations thus covering a wide range of $\eta$ values. The stations used for Fig. 1 were the following: NASA/Goddard Space Flight Center (GSFC) in the vicinity of Washington DC (USA) for cases of anthropogenic aerosol predominance; Solar Village, located in the desert of the Arabian Peninsula for dust predominance; Mongu, located in the African savannas of Zambia for biomass-burning aerosols; and, finally, for mixtures of dust with pollution or biomass burning, FORTH (Foundation for Research \& Technology) Crete on the island of Crete (Greece) and Hamin in the United Arab Emirates. More information about these sites can be found on the AERONET web page (http://aeronet.gsfc.nasa.gov/).

From Fig. 1 we observe a generally linear relationship between $\eta$ and $\alpha(440-870)$, with the corresponding leastsquares fit being $\eta=0.369 \alpha(440-870)+0.167$. The linear fit has a correlation coefficient of $R^{2}=0.934$ thus providing an easy way to estimate the contribution of fine mode from 
$\alpha(440-870)$. Also, different aerosol types are generally characterized by different values of $\eta$ : for biomass-burning and anthropogenic pollution, normally large values of $\eta$ are observed (mean values $\eta>0.8$ ), while for dust mean $\eta$ is much lower $(<0.35)$. Finally, for mixtures of different aerosol types $\eta$ takes intermediate values between 0.35 and 0.8 .

Simulations have revealed that the inversion results are sensitive to the values of $r_{\min }$ and $r_{\max }$ permitted for the search space (e.g. Veselovskii et al., 2012). For example, when fine particles present more relevance in particle size distribution (e.g. anthropogenic or biomass-burning aerosol) retrievals can be improved by decreasing the value of $r_{\max }$, while when coarse particles predominate (e.g. dust aerosol) the results could be improved by increasing both $r_{\min }$ and $r_{\max }$. Therefore, the appropriate search space $\left[r_{\min }, r_{\max }\right]$ can be established for different types of aerosol in order to optimize the inversions and the $\eta$ parameter is useful for establishing that interval. For example, Fig. 2 shows columnar volume size distributions (PSDs) for different aerosol types at different values of $\eta$ obtained by averaging all AERONET Level 2.0 PSDs obtained at the five reference sites used. The procedure followed consisted of normalizing each PSD and later doing the averages. Based on the results of Fig. 2, the following inversion intervals were chosen: (i) for $\eta \leq 0.25, r_{\min }=0.20 \mu \mathrm{m}$ and $r_{\max }=10 \mu \mathrm{m}$ since the main part of aerosol PSD is contained in the coarse mode. (ii) For $0.25<\eta \leq 0.5$ a wider range of radii is considered, i.e., $r_{\min }=0.05 \mu \mathrm{m}$ and $r_{\max }=10 \mu \mathrm{m}$, to account for both fine and coarse mode particles. (iii) For $0.5<\eta \leq 0.75$ so $r_{\min }=0.05 \mu \mathrm{m}$ and $r_{\max }=5 \mu \mathrm{m}$ as the main part of aerosol PSD is in the in the fine mode. (iv) Finally, for $\eta>0.75$ only fine mode is considered and thus $r_{\min }=0.05 \mu \mathrm{m}$ and $r_{\max }=2 \mu \mathrm{m}$. In order to best stabilize the inversion, these ranges in fact neglect a small percentage of the PSD.

Finally, the real part of the refractive index $\left(m_{\mathrm{r}}\right)$ is allowed to vary from 1.35 to 1.65 with a stepsize of 0.025 , while the imaginary part $\left(m_{\mathrm{i}}\right)$ varies from 0 to 0.015 with a step size of 0.005 . These refractive index ranges are used both for simulated and measured data.

\section{Sensitivity analysis}

Before applying the LE inversion algorithm to AOD measurements a sensitivity study was performed. The simulations were performed assuming a bimodal aerosol size distribution:

$$
\frac{\mathrm{d} \boldsymbol{n}(r)}{\mathrm{d} \ln (r)}=\sum_{i=\mathrm{f}, \mathrm{c}} \frac{N_{t, i}}{(2 \pi)^{1 / 2} \ln \sigma_{i}} \exp \left[\frac{\left(\ln r-\ln r_{i}^{n}\right)^{2}}{2\left(\ln \sigma_{i}\right)^{2}}\right],
$$

where $N_{i}$ is the total number of particles of the $i$ th mode, $\ln \left(\sigma_{i}\right)$ is the mode width of the $i$ th mode and $r_{i}^{n}$ is the mode radius. The index $i=$ "f" and "c" corresponds to the fine mode and the coarse mode, respectively. The fine mode is

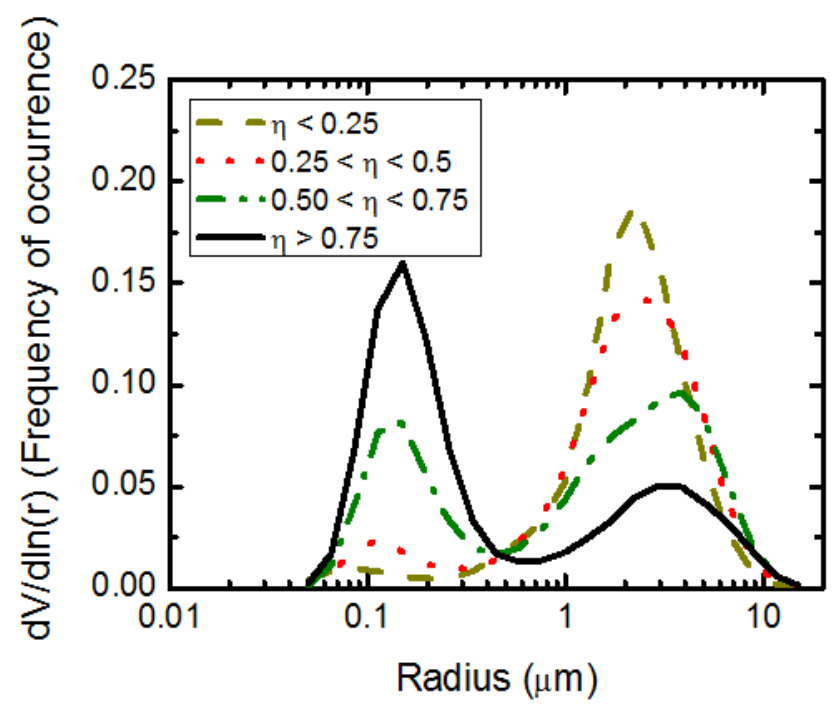

Figure 2. Average volume size distributions for different ranges of fine mode fraction $(\eta)$. We used all the normalized size distributions for the five reference AERONET sites at Goddard Space Flight Center, Mongu, Solar Village, FORTH Crete and Hamin.

taken to include all particles with radius between 0.05 and $0.5 \mu \mathrm{m}$ while the coarse mode includes all particles with radius between 0.5 and $5 \mu \mathrm{m}$.

On the other hand, the same distribution can be written for volume concentration $\boldsymbol{v}(\mathrm{r})$, which is usually preferred because doing so permits both fine and coarse mode to be easily distinguished. Moreover, the standard deviations of $\boldsymbol{n}(r)$ and $\boldsymbol{v}(r)$ are the same when using the relationships between radius and concentrations for each mode given by the following (Horvath et al., 1990):

$$
\begin{aligned}
& r_{i}^{v}=r_{i}^{n} \exp \left[3\left(\ln \sigma_{i}\right)^{2}\right], \\
& V_{t i}=N_{t i} \frac{4}{3} \pi\left(r_{i}^{n}\right)^{3} \exp \left[\frac{9}{2}(\ln \sigma)^{2}\right] .
\end{aligned}
$$

The retrievals of the effective radius $\left(r_{\text {eff }}\right)$ and the particle volume $(V)$ by LE are done using the measurements of the CIMEL sun-photometers at 380, 440, 670, 870 and $1020 \mathrm{~nm}$. Those wavelengths are available in almost every CIMEL sun photometer of AERONET. Retrievals can be improved if measurements centered at $1640 \mathrm{~nm}$ are added. But as the use of such a filter is a recent upgrade of the AERONET network and currently operates in $\sim 1 / 3$ of the stations, the use of $1640 \mathrm{~nm}$ was excluded from consideration in this study.

\subsection{Uncertainty of retrievals}

The sensitivity test considers two different scenarios; the first that varies the fine mode radius and the second that varies the coarse mode fraction. In "Scenario I" the ratio $N_{\mathrm{c}} / N_{\mathrm{f}}=10^{-4}$ 
and $r_{\mathrm{c}}^{v}=1.62 \mu \mathrm{m}$ are kept constant while $r_{\mathrm{f}}^{v}$ varies from 0.1 to $0.3 \mu \mathrm{m}$. In "Scenario II" the radii of both modes are fixed at $r_{\mathrm{f}}^{v}=0.14$ and $r_{\mathrm{c}}^{v}=1.62 \mu \mathrm{m}$, respectively, while the ratio $N_{\mathrm{c}} / N_{\mathrm{f}}$ varies from $10^{-4}$ to $10^{-1}$. The maximum value of $N_{\mathrm{c}} / N_{\mathrm{f}}$ was chosen by analyzing the AERONET measurements at Solar Village, Hamin and FORTH Crete: for more $\sim 10000$ retrievals with $\alpha(440-870)<0.5$, there were none with $N_{\mathrm{c}} / N_{\mathrm{f}}>0.15$ and only four with $0.10<N_{\mathrm{c}} / N_{\mathrm{f}}<0.15$ $(0.15 \%)$. Therefore we only consider $N_{\mathrm{c}} / N_{\mathrm{f}}<0.2$ in our simulations. Both for Scenario I and II, the standard deviations of both modes are $\ln \left(\sigma_{i}\right)=0.4$, and also the refractive index value is $1.40+0.001$ and independent of wavelength. The input optical data $\operatorname{AOD}(\lambda)$ for the simulations are calculated for the chosen PSDs via Mie theory. The input data are assumed to be free of errors, so the errors in the retrievals are mainly due to the existence of a "null space" in the inversion and to the ambiguity of the choice of a solution family (Veselovskii et al., 2012, 2013). Figure 3 shows the results of the relative differences $\left(X_{\text {retrieved }}-X_{\text {model }}\right) / X_{\text {model }}$ (where " $X$ " is either $r_{\text {eff }}$ or $V$ ) for the different ranges of $r_{\mathrm{f}}^{v}$ of Scenario I. The effective radius shows that the relative difference decreases from $\sim 60 \%$ at $0.10 \mu \mathrm{m}$ to $\sim 20 \%$ for $r_{\mathrm{f}}^{v}=0.20 \mu \mathrm{m}$. For larger values of $r_{\mathrm{f}}^{v}$ the relative differences does not vary significantly. The relative difference in columnar volume aerosol content shows an increase from -20 to $\sim 40 \%$ for the range of $r_{\mathrm{f}}^{v}=0.1 \mu \mathrm{m}$ to $r_{\mathrm{f}}^{v}=0.2 \mu \mathrm{m}$, above which the relative differences are approximately constant at $40 \%$. We can explain these patterns because the inversion is less sensitive to particles of radius below $\sim 0.05 \mu \mathrm{m}$ due to the range of wavelengths available in the input data. Nevertheless, for $r_{\mathrm{f}}^{v}$ between 0.12 and $0.3 \mu \mathrm{m}$, which is typical of cases where the fine mode predominates, the linear estimation results possess relative difference of $\sim 20 \%$ for $r_{\text {eff }}$ and of $\sim 40 \%$ for columnar volume aerosol content.

Figure 4a shows the relative differences of $r_{\text {eff }}$ and Fig. $4 \mathrm{~b}$ those of $V$ for the different $N_{\mathrm{c}} / N_{\mathrm{f}}$ of Scenario II. We show the results for the range of constraints on the inversion previously discussed and also those with maximum radius in the inversions of 5 and $10 \mu \mathrm{m}$. Both Fig. $4 \mathrm{a}$ and $\mathrm{b}$ reveal that constraining the inversions to a reduced range of permitted values reduces the relative differences. For coarse mode predominance the importance of a well-constrained inversion is even clearer. For the constrained inversions, particle volume reveals only remarkable differences (approximately 15\%) for $N_{\mathrm{c}} / N_{\mathrm{f}}>0.095$ (large predominance of coarse mode), while effective radius present an uncertainty below $20 \%$ for all the range of $N_{\mathrm{c}} / N_{\mathrm{f}}>0.095$ (between 0.015 and 0.1). On the other hand, the largest relative differences, both for $r_{\text {eff }}$ and $V$, are found for the ranges where both modes have similar contribution to PSD. This reveals the difficulty of inverting such mixed cases where the range of the inversion cannot be constrained as much. The thus required wider inversion intervals cause the differences between the retrievals and the

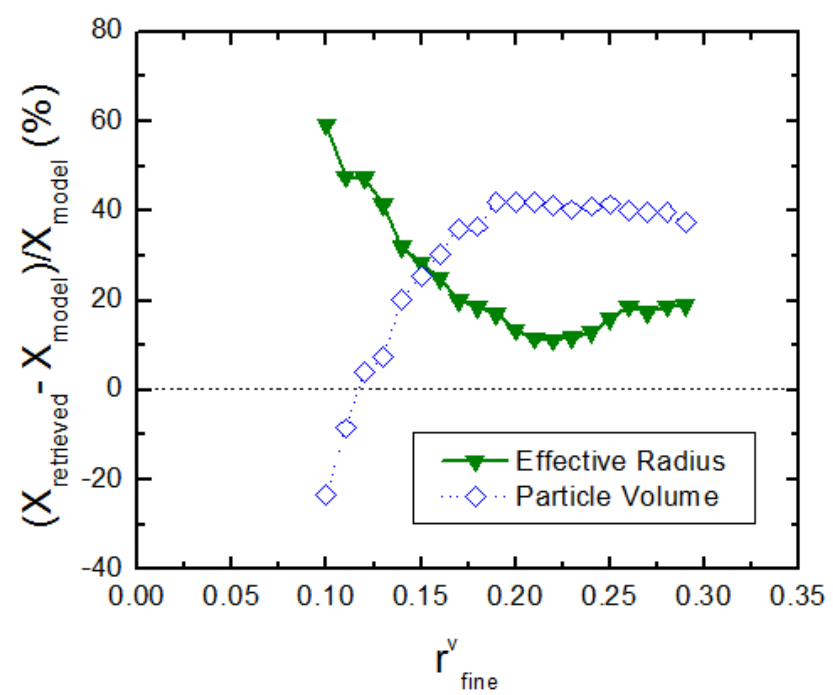

Figure 3. Relative differences of effective radius and columnar volume aerosol content vs. the fine mode effective radius of the input model size distribution. Data correspond to Scenario I.

reference to increase to $\sim 40 \%$ for $r_{\text {eff }}$ and $\sim 30 \%$ for particle volume.

We also note that aerosol cross section depends on refractive index and so will the retrievals. The simulations performed both for Scenarios I and II (graphs not shown), however, revealed that differences of less than $40 \%$ arise between fixing the refractive index to their real values and allowing the index of refraction to vary within the range mentioned.

\section{Results}

\subsection{Retrieval of aerosol microphysical properties with improved temporal resolution}

The ability to obtain higher temporal resolution aerosol microphysical property retrievals by inversion of AODs (as compared with the AERONET operational retrieval) is illustrated in Fig. 5. This Figure uses data obtained at GSFC on 2 June 2000. Mean AOD at $440 \mathrm{~nm}(\operatorname{AOD}(440))$ for this day is about 0.77 and the Angström exponent $\alpha(440-870)$ is about 1.88 , implying by reference to Fig. 1 that aerosol particles are rather small. The backward-trajectory analysis obtained from the HYSPLIT model (Draxler and Rolph, 2003) revealed that the high values of $\alpha(440-870)$ and high aerosol loading are due to air masses with origins in the industrial areas of the east coast of the US. For this particular day, only four Level 2.0 AERONET retrievals were available, compared to 27 AOD measurements. Figure 5 shows reasonable agreement between the two retrieval techniques when both are present. The effective radius is quite stable during the day while $V$ follows a daily pattern similar to that for $\operatorname{AOD}(440)$. 


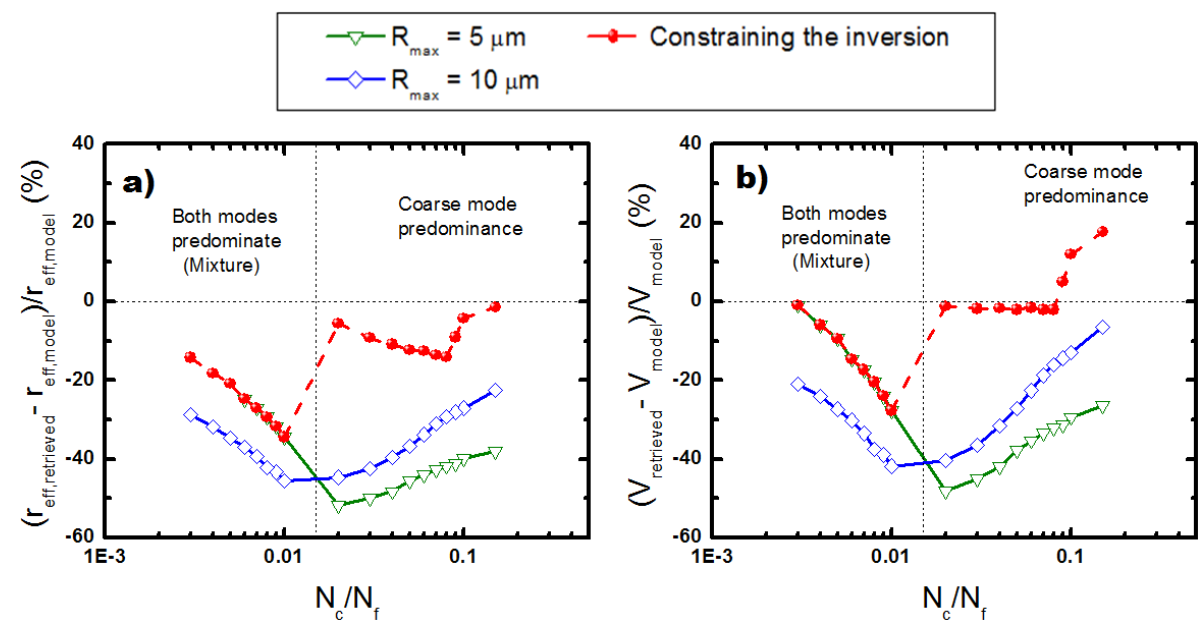

Figure 4. (a) Relative difference in the effective radius and (b) in columnar volume aerosol content vs. the fraction between coarse and fine number of particles $\left(N_{\mathrm{c}} / N_{\mathrm{f}}\right)$. Data correspond to Scenario II.

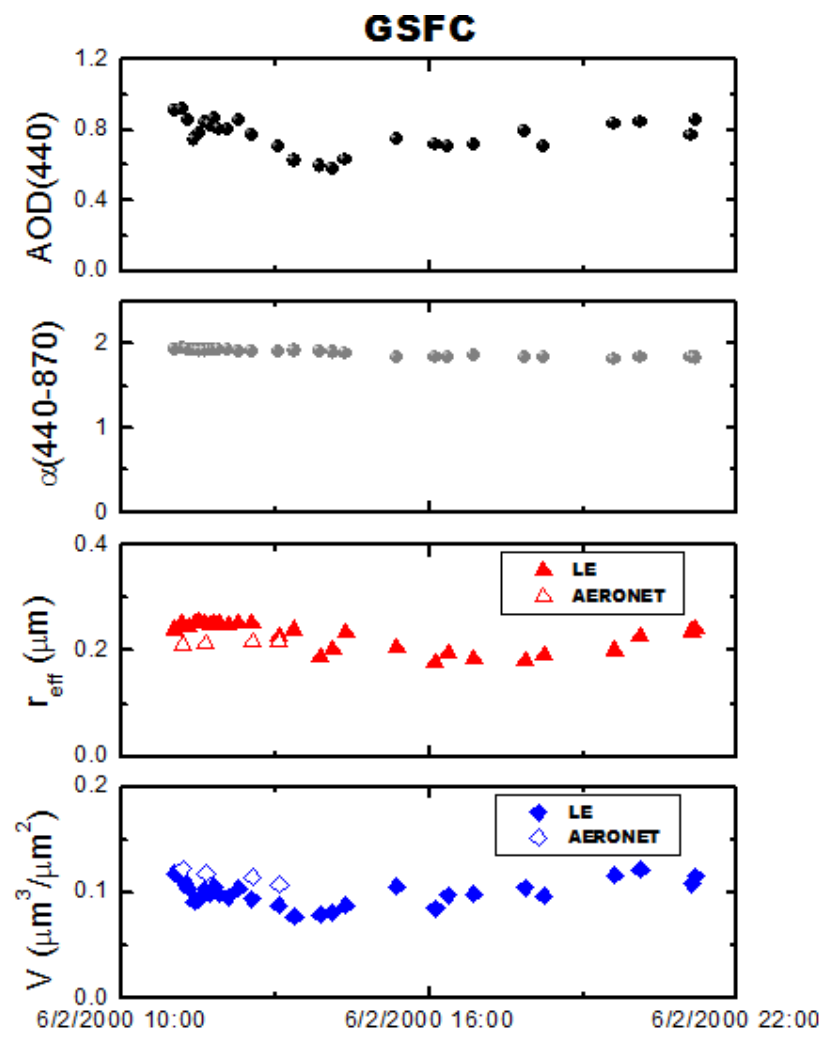

Figure 5. Time evolutions of aerosol optical depth $(\mathrm{AOD}(440))$ and Ångström parameter $(\alpha(440-870))$ from AERONET Level 2.0 data at Goddard Space Flight Center on 2 June 2000. Also effective radius $\left(r_{\text {eff }}\right)$ and columnar volume aerosol content $(V)$ are shown, both for operational AERONET (open symbols) and linear estimation (full symbols) retrievals.

Figure 6 shows a similar analysis for the data obtained at Solar Village on 6 July 2000. This case is characterized by high aerosol load $(\operatorname{AOD}(440) \sim 1.2)$ and low Ångström exponent $(\alpha(440-870)<0.2)$, indicating a predominance of coarse particles. The 5-day backward trajectories by HYSPLIT revealed air masses with origins over the Arabian Peninsula, and thus the presence of dust was expected. On this day only three Level 2.0 AERONET inversions were available compared to 43 AOD measurements. The effective radius obtained with $\mathrm{LE}$ is about $1.0 \mu \mathrm{m}$ during most of the day and is lower than those provided by AERONET ( $\sim 1.4 \mu \mathrm{m})$. The columnar volume aerosol content provided by LE is also systematically lower $(\sim 30 \%)$.

Finally, Fig. 7 shows the time evolution of aerosol optical and microphysical properties at FORTH Crete on 26 July 2004. The 5-day backward trajectories from HYSPLIT indicated that early in the morning the air masses had their origins over the southeast of the European continent and likely contained pollutants (e.g. Fotiadi et al., 2006; Gerasopoulos et al., 2003, 2011). Also, fires in western Russia during the preceding days (see http://rapidfire.sci.gsfc.nasa. gov/firemaps/) may have transported biomass-burning particles (e.g. Balis et al., 2003; Amiridis et al., 2009). Later in the afternoon, the air masses reaching the area at altitudes of 1500 and $3000 \mathrm{~m}$ changed direction and had their origin over the Saharan desert and thus may have transported dust particle of larger sizes (e.g. Papayannis et al., 2005, 2012). The NAAPS model (http://www.nrlmry.navy. mil/aerosol/) reveals changes of particle types during this day and suggests large contribution of fine particles in the morning and comparable contribution of fine and coarse particles in the afternoon.

The variability of the aerosol properties observed in FORTH Crete on 26 July 2000 is captured by the high temporal resolution LE inversions. The effective radius continuously increases during the day, varying from $\sim 0.24 \mu \mathrm{m}$ early in the morning to $\sim 0.50 \mu \mathrm{m}$ in the evening. The columnar 

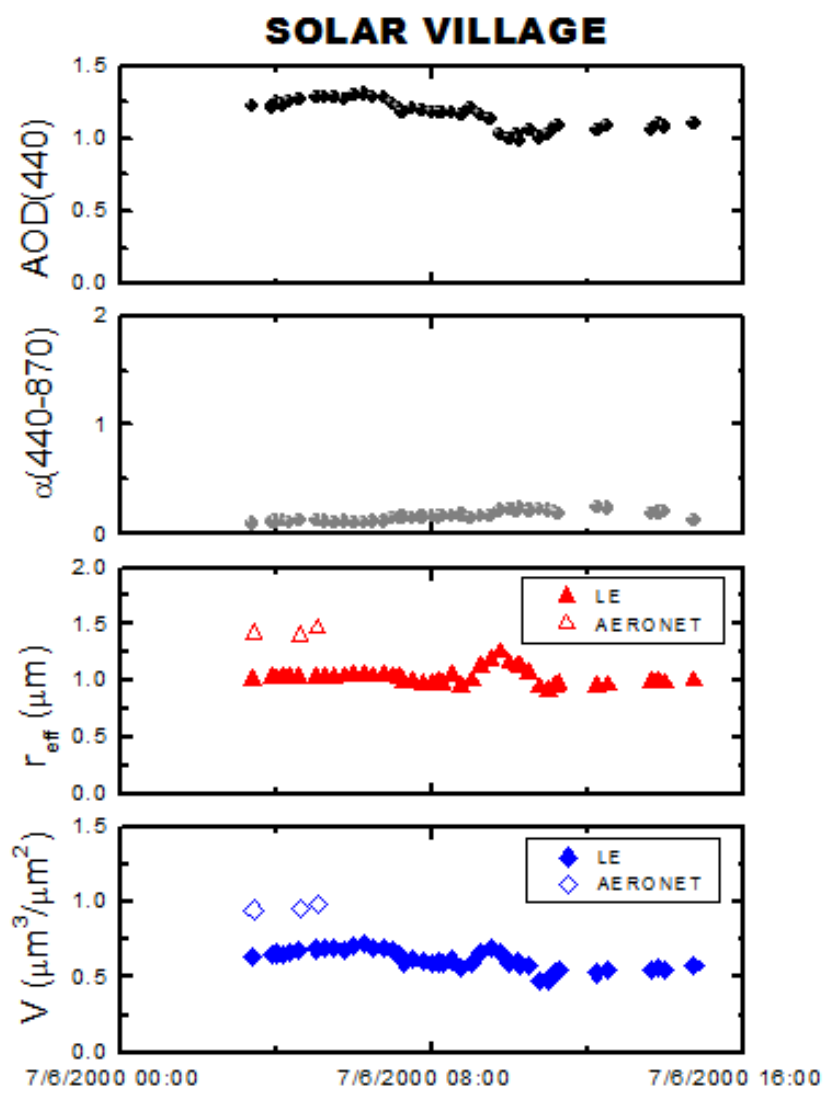

Figure 6. Time evolutions of aerosol optical depth $(\mathrm{AOD}(440))$ and Ångström parameter $(\alpha(440-870))$ from AERONET Level 2.0 data at Solar Village on 6 July 2000. Also effective radius $\left(r_{\text {eff }}\right)$ and columnar volume aerosol content $(V)$ are shown, both for operational AERONET (open symbols) and linear estimation (full symbols) retrievals.

volume aerosol content also shows a continuous increase from $\sim 0.050$ to $\sim 0.170 \mu \mathrm{m}^{3} \mu \mathrm{m}^{-2}$. For the effective radius there is good agreement between the operational AERONET and LE retrievals, while $V$ is still underestimated by LE compared to the operational AERONET retrievals.

The retrievals of particle parameters for larger temporal periods are illustrated in Fig. 8 (effective radius) and Fig. 9 (columnar volume aerosol content). The temporal periods selected are the following: 6 months at GSFC, where pollution events were common; 1 month in Mongu during an intense biomass-burning period; 4 months in Solar Village, which frequently experienced high dust loading; and 4 months in FORTH Crete, which was characterized by events of mixed aerosol types. For simplicity, in both Figs. 8 and 9 LE retrievals are only shown for periods when the operational AERONET retrievals were also available.

Figures 8 and 9 reveal that both LE and the operational AERONET retrievals lead to similar temporal patterns. Agreements between these inversion techniques are especially good for the aerosol characterized by the predomi-

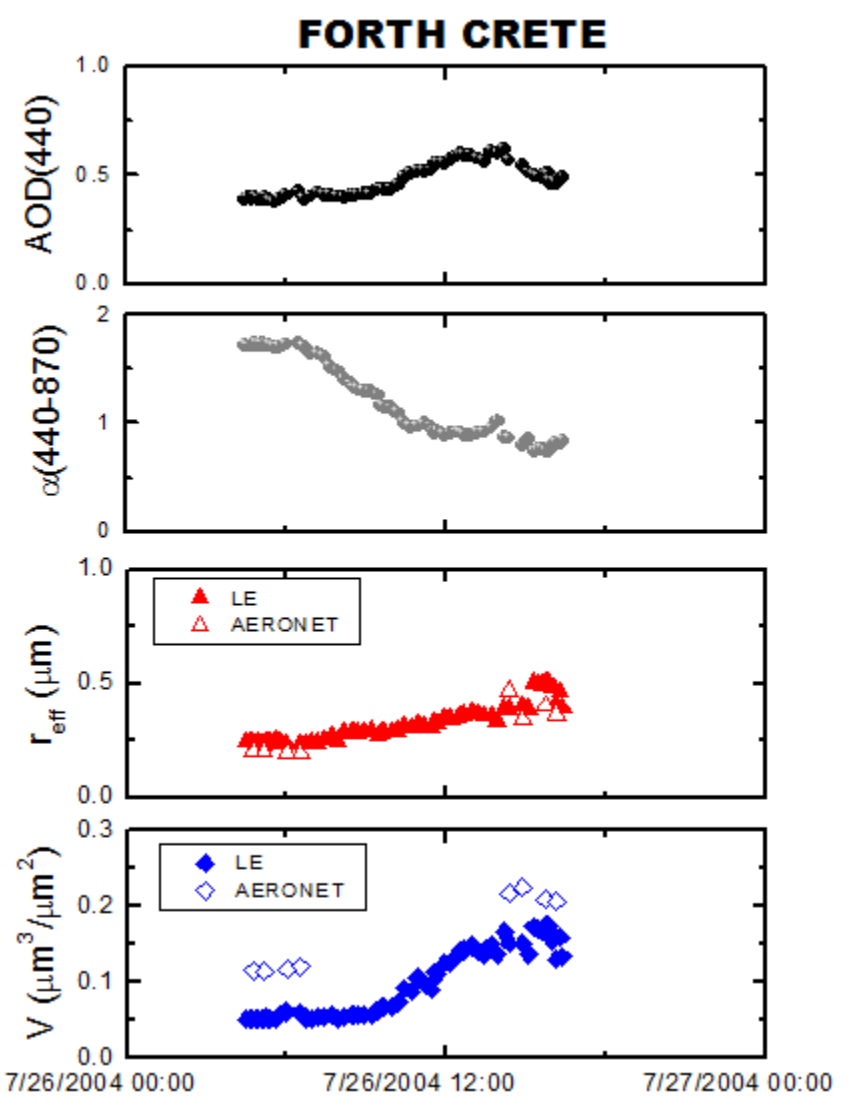

Figure 7. Time evolutions of aerosol optical depth (AOD(440)) and Ångström parameter $(\alpha(440-870))$ from AERONET Level 2.0 data at FORTH Crete on 26 July 2004. Also effective radius $\left(r_{\text {eff }}\right)$ and columnar volume aerosol content $(V)$ are shown, both for operational AERONET (open symbols) and linear estimation (full symbols) retrievals.

nance of the fine mode (GSFC and Mongu), while the LE retrievals systematically underestimate $r_{\text {eff }}$ and $V$ when the coarse mode predominates. Those discrepancies are particularly remarkable for dust particles at Solar Village and for Saharan dust outbreaks at FORTH Crete. But the cases with the largest differences are those with mixtures of different types. Those discrepancies can be partly explained by the uncertainties of LE retrievals described in Sect. 3. However, as the current AERONET algorithm and LE uses different approaches, such discrepancies (biases) between both approaches should be studied and their impact minimized through correction functions.

\subsection{Correction of the linear estimation retrievals}

To compute correction functions for the AOD based on LE retrievals, the operational AERONET results are used as the reference and a function is determined that adjusts the LE results to this reference. The analysis is done by studying the differences between LE and AERONET retrievals as a 

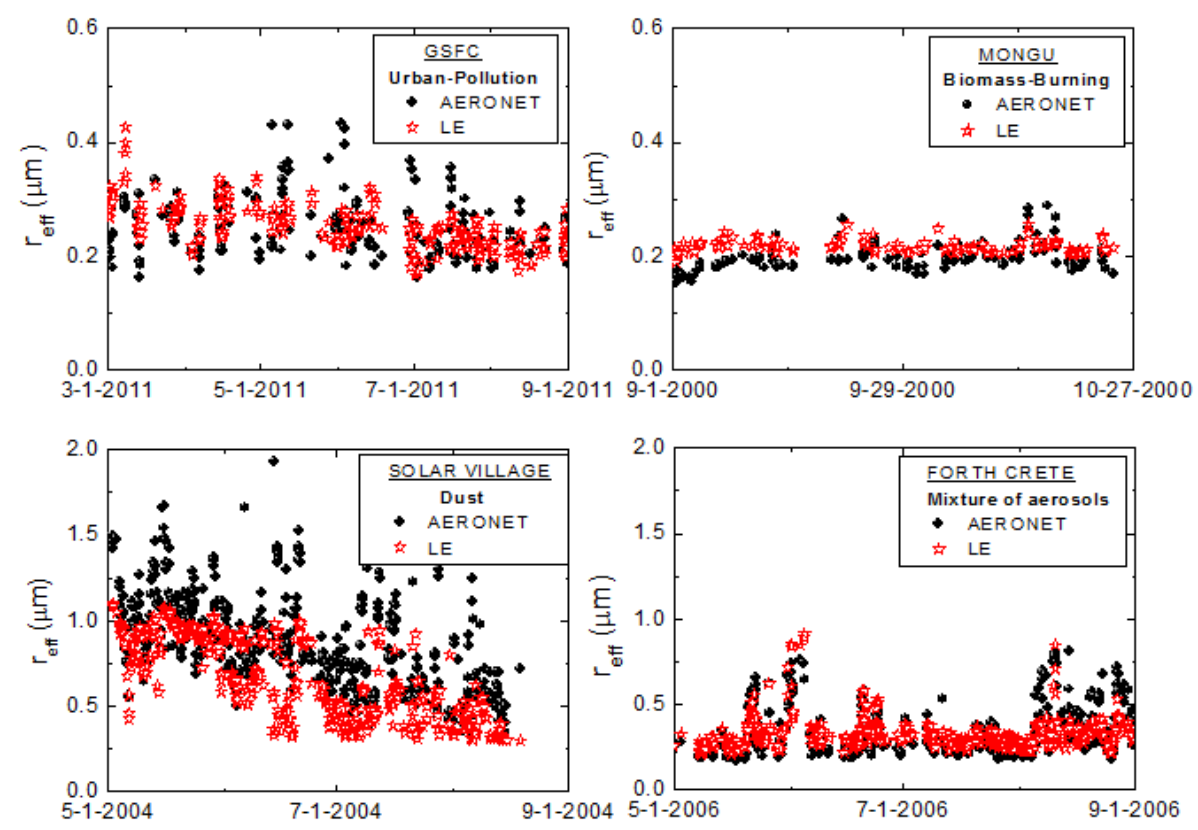

Figure 8. Long-term time evolutions of effective radius $\left(r_{\text {eff }}\right)$ obtained both by linear estimation (LE) and AERONET retrievals for places with very different aerosol characteristics.
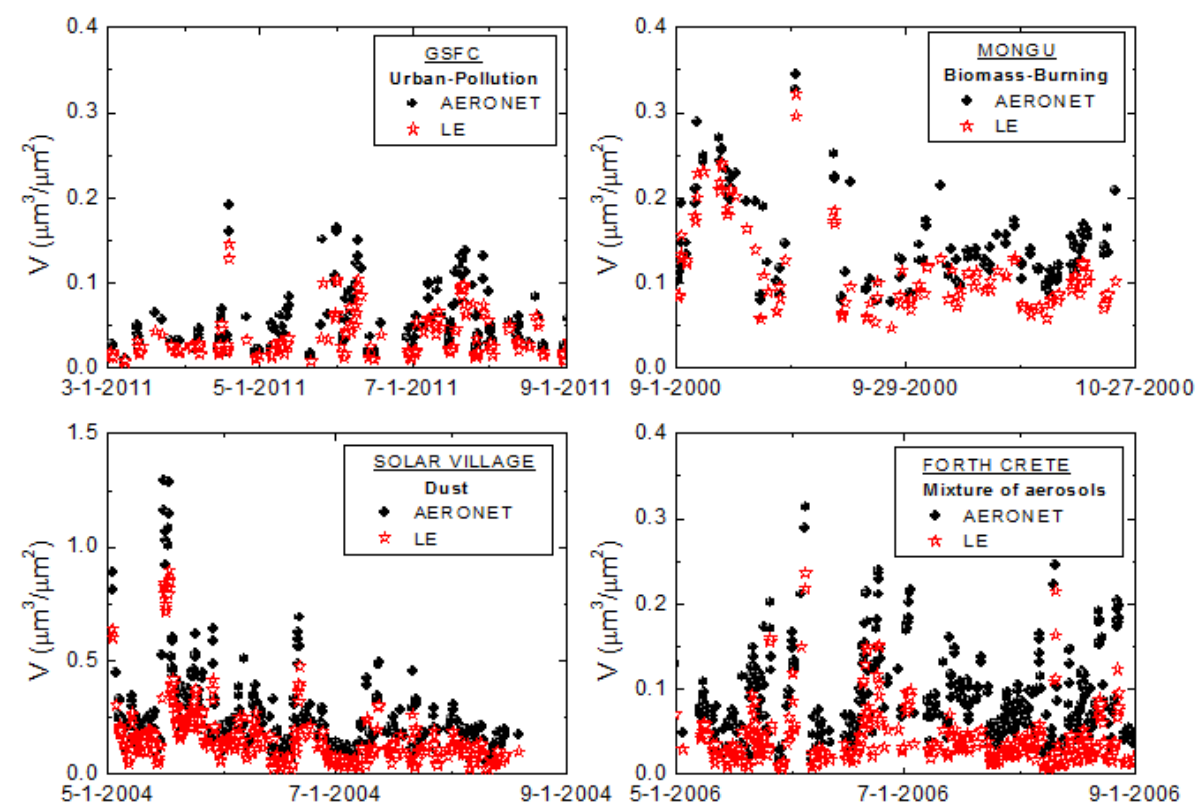

Figure 9. Long-term time evolutions of columnar volume aerosol content $(V)$ obtained both by linear estimation (LE) and AERONET retrievals for places with very different aerosol characteristics.

function of $\eta$. All AERONET Level 2.0 measurements at the selected reference sites through 2013 were used.

Figure 10a plots the relative difference $\Delta r_{\text {eff }}=\left(r_{\text {eff }}^{\mathrm{LE}}-\right.$ $\left.r_{\text {eff }}^{\mathrm{AERONET}}\right) / r_{\text {eff }}^{\mathrm{AERONET}}$ vs. $\eta$. Here, $r_{\mathrm{eff}}^{\mathrm{LE}}$ and $r_{\text {eff }}^{\mathrm{AERONET}}$ are the effective radii provided by $\mathrm{LE}$ and the operational AERONET code, respectively. The correction functions are computed by averaging these relative differences for 10 in- tervals of $\eta$ from 0 to 1 , as shown in Fig. 10b. In order to apply a correction for the different ranges of the constraints in the inversion, we perform linear fits $\Delta r_{\text {eff }}=A \eta+B$ (as shown in Fig. 10b), where the parameters for these fits are summarized in Table 1.

To study the current correction functions, simulations based on Mie theory were performed using the PSDs of 

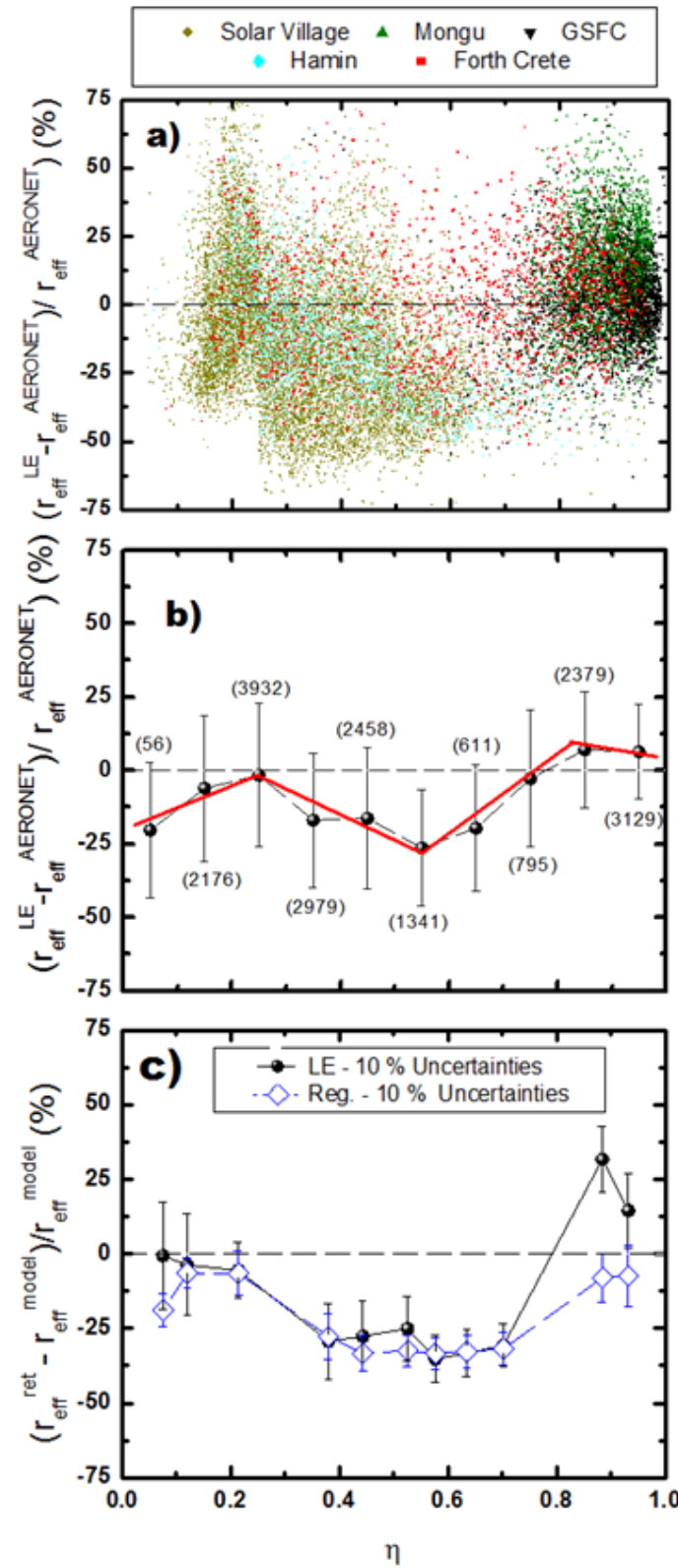

Figure 10. Relative differences of the effective radius obtained by linear estimation $\left(r_{\mathrm{eff}}^{\mathrm{LE}}\right)$, and those obtained by AERONET $(r$ eff AERONET $)$ for (a) all the data points from the selected AERONET reference sites and (b) average values. The red lines represent the different linear fits performed. Number in parenthesis indicates the number of intercomparisons for the above/below point. Also, (c) relative differences between model $\left(r_{\text {eff }}^{\text {model }}\right)$ and retrieved $\left(r_{\text {eff }}^{\text {ret }}\right)$ data for fixed particle size distributions. Results are based on simulated data. Linear estimation and regularization techniques are included, and $10 \%$ noise is introduced.

Sect. 3 (fine mode radius of $0.14 \mu \mathrm{m}$, coarse mode radius of $1.62 \mu \mathrm{m}$ and width of each mode of 0.4 ) but changing the ratio $N_{\mathrm{c}} / N_{\mathrm{f}}$ in order to cover the different intervals of $\eta$. We simulated the optical data consistent with these dis-
Table 1. Correction functions computed by fitting LE retrievals to those of the operational AERONET code. We perform linear fits $\Delta r_{\mathrm{eff}}=A \eta+B$ for the effective radius and $\Delta V=A \eta+B$ for particle volume.

\begin{tabular}{lrrr}
\hline & $\begin{array}{r}\text { Fine mode fraction } \\
\text { interval }(\eta)\end{array}$ & A & B \\
\hline Effective & $\eta \leq 0.25$ & 93 & -23 \\
radius & $0.25<\eta \leq 0.50$ & -74 & 14 \\
& $0.50<\eta \leq 0.75$ & 118 & -93 \\
& $\eta>0.75$ & -7 & 13 \\
\hline Particle & $\eta \leq 0.25$ & -11 & 30 \\
volume & $0.25<\eta \leq 0.50$ & -59 & -18 \\
& $0.50<\eta \leq 0.75$ & 34 & -70 \\
& $\eta>0.75$ & 111 & -129 \\
\hline
\end{tabular}

tributions, inverted the optical data to aerosol microphysics using both the linear estimation and regularization (Müller et al., 1999a, b; Veselovskii et al., 2002) techniques, and then compared these inversions to the original distributions. Prior to inverting to microphyiscs, we also introduce $10 \%$ normally distributed random uncertainties in the input optical data to simulate uncertainties in the real measurements and repeat the procedure 10000 times. The value of $10 \%$ is an estimate of the uncertainty in AOD for AOD values of 0.10 (Holben et al., 1998). The results for $r_{\text {eff }}$ are shown in Fig. 10c and as can be seen, the patterns of LE and regularization are very similar except for the cases of fine particle predominance where the LE results yield 20-30\% larger values of $r_{\text {eff }}$ than those of regularization. Also we note the similarity between these results and the correction functions of Figure 10b. Similarly, Fig. 11a shows the relative difference $\Delta V=\left(V^{\mathrm{LE}}-V^{\mathrm{AERONET}}\right) / V^{\mathrm{AERONET}}$ vs. $\eta$, where $V^{\mathrm{LE}}$ and $V^{\text {AERONET }}$ are the columnar volume aerosol contents retrieved by LE and by the operational AERONET code respectively. For columnar volume aerosol content there is systematic underestimation of AERONET values, especially for $0.3<\eta<0.9$. Again, linear fits $\Delta V=A \eta+B$ were done, where the parameters for these fits are reported in Table 1 as well. Moreover, we performed simulations in the same manner as for the effective radius shown in Fig. 10. The results of these simulations are in Fig. 11c. Again the pattern obtained by LE and regularization are generally similar. But we observe significant differences compared to the corrections functions of Fig. 11b, both for coarse and fine mode dominant cases. We also note that retrievals of columnar volume aerosol content by inverting AODs possess larger uncertainties than retrievals based on the full AERONET data set due to the more limited information. While further studies of these differences would be desirable (NASA SMD Workshop Atmospheric Composition Outstanding Questions (https:// espo.nasa.gov/home/content/NASA_SMD_Workshop), such studies are beyond the scope of the present work. 

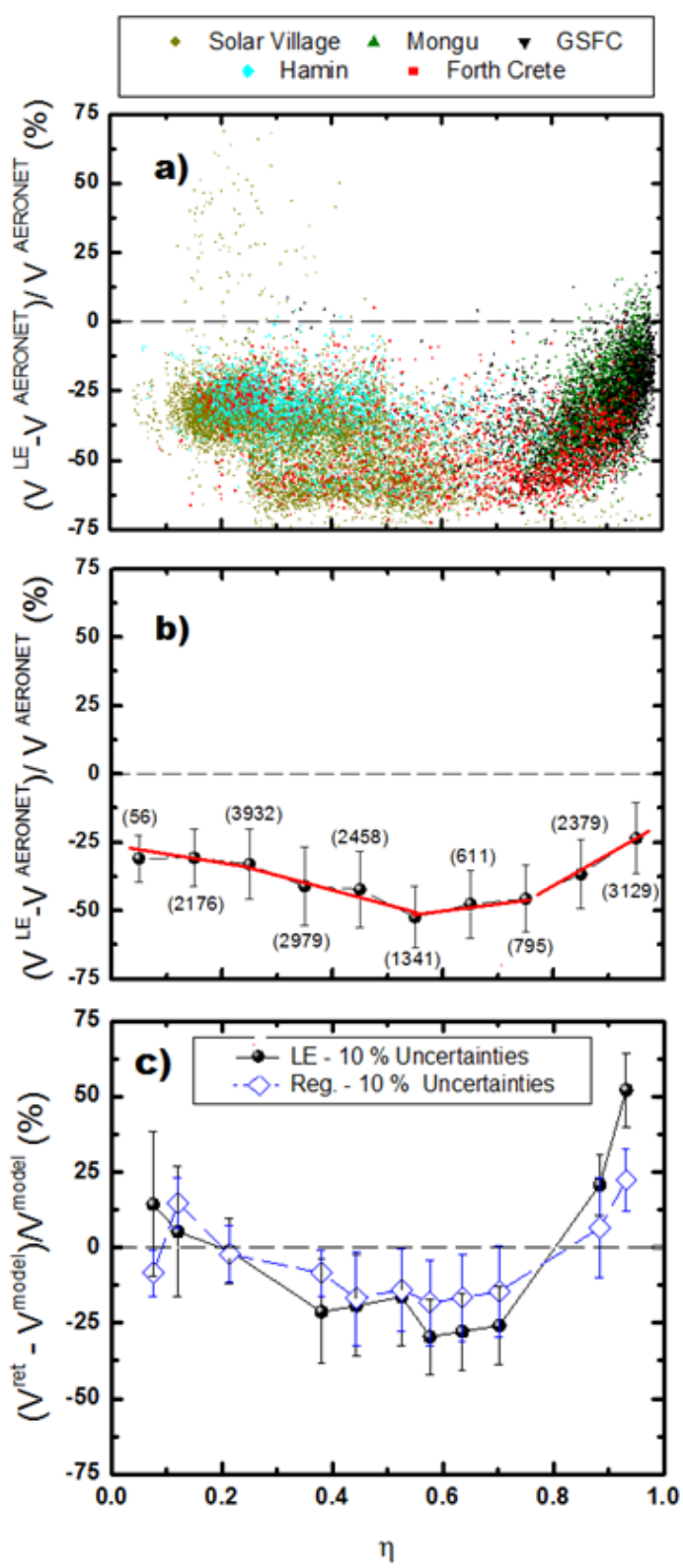

Figure 11. Relative differences of the columnar volume aerosol content obtained by linear estimation $\left(V^{\mathrm{LE}}\right)$ and those obtained by AERONET ( $V^{\text {AERONET }}$ ) for (a) all the data points from the selected AERONET reference sites and (b) average values. The red lines represent the different linear fits performed. Number in parenthesis indicates the number of intercomparisons for the above/below point. Also, (c) relative differences between model $\left(V^{\text {model }}\right)$ and retrieved $\left(V^{\text {ret }}\right)$ data for fixed particle size distributions. Results are based on simulated data. Linear estimation and regularization techniques are included, and $10 \%$ noise is introduced.

To evaluate the proposed correction functions, 18 AERONET stations, different from those used to generate the correction, were selected. These sites, listed in Table 2, present different aerosol types: anthropogenic pollution $(\mathrm{P})$, biomass-burning (BB) and dust (D). The sites are located in urban $(\mathrm{U})$, remote areas $(\mathrm{R})$ or in coastal area $(\mathrm{C})$. Table 2 also provides mean values of $\mathrm{AOD}(440)$ and $\alpha(440-870)$ at each site. We use all AERONET Level 2.0 data through 2013 at each site and create a data set of more than 75000 comparisons between the operational AERONET and LE algorithms.

Table 3 presents mean relative differences $\Delta r_{\text {eff }}$ and $\Delta V$ and standard deviations averaged over all 75000 observations before and after correction for the four ranges of $\eta$ used. The results of Table 3 indicate a reduction of the differences between LE and AERONET retrievals after applying the corrections. The mean values of the relative differences are now closer to zero, and the standard deviations are smaller. Still, after correction the largest differences and dispersions are found for $\eta \leq 0.25$, i.e. for the aerosol characterized by coarse mode predominance. But overall, the corrections to the LE retrievals yield mean differences when compared with the AERONET operational code of below $\pm 10 \%$, while dispersions are less than $45 \%$.

The improvement in the LE retrievals after correction is also illustrated by the frequency distributions of $\Delta V$ in Fig. 12. Before correction, all distributions are biased toward negative differences. But after applying the correction, as expected, we observe a large reduction in the bias with mean differences close to zero. Similar frequency distributions were also done for the effective radius retrieval (not shown) with a similar improvement occurring after applying corrections.

The values of $\Delta r_{\text {eff }}$ and $\Delta V$, before and after correction for each individual site are also shown in Table 2. An improvement is observed at most sites, and after correction the maximum mean relative differences do not exceed $\pm 15 \%$ both for effective radius and columnar volume aerosol content. The mean differences higher than $\pm 10 \%$ after corrections at some locations is due to the data at those locations being outliers of the correction functions (e.g. Figs. 9 and 10). This illustrates the difficulty of obtaining a general correction for every location and aerosol type.

\subsection{Day-to-night time evolution of columnar microphysical properties retrieved from sun-and-star-photometry measurements}

The LE inversion described in the previous sections can be also applied to star-photometer measurements. Star photometers cannot acquire sky radiance measurements due to both the low signal and the presence of other stars, and thus to get aerosol microphysical properties an approach that uses only AODs is needed. This study uses star-photometry measurements acquired at the station of Granada, Spain (see specifications in Table 2). This star photometer has been operating since 2008, and it uses a CCD camera as a detector. From direct star irradiance measurements this instrument can obtain $\operatorname{AOD}(\lambda)$ at $380,436,500,670,870$ and 
Table 2. AERONET sites used to evaluate the correction functions of Table 1. The stations are defined according to their aerosol types such as desert (D), biomass-burning (BB) or anthropogenic pollution (P). Also it is include if they are remote (R), urban (U) or coastal (C). The mean aerosol optical at $440 \mathrm{~nm}\left(\mathrm{AOD}_{\text {mean }}\right)$ and $\AA$ ngström parameter between $440-870 \mathrm{~nm}\left(\alpha_{\text {mean }}\right)$ are included. Also, the mean and standard deviations of the differences between linear estimation and the operational AERONET code, before and after applying corrections, are included both for effective radius $\left(r_{\text {eff }}\right)$ and columnar volume aerosol content $(V)$.

\begin{tabular}{|c|c|c|c|c|c|c|c|c|c|c|c|c|c|c|}
\hline \multirow[b]{2}{*}{ Place } & \multirow[b]{2}{*}{ Latitude } & \multirow[b]{2}{*}{ Longitude } & \multirow[b]{2}{*}{$\begin{array}{l}\text { Height } \\
\text { (m a.s.1.) }\end{array}$} & \multirow[b]{2}{*}{ Type } & \multirow[b]{2}{*}{$\mathrm{AOD}_{\text {mean }}$} & \multirow[b]{2}{*}{$\alpha_{\text {mean }}$} & \multicolumn{2}{|c|}{$\frac{\left(r_{\text {eff }}^{\mathrm{LE}}-r_{\text {eff }}^{\mathrm{AERONET}}\right)}{r_{\text {eff }}^{\mathrm{AERONET}}}$} & \multirow{2}{*}{\multicolumn{2}{|c|}{$\begin{array}{l}\text { After } \\
\text { correction }\end{array}$}} & \multicolumn{2}{|c|}{$\frac{\left(V^{\mathrm{LE}}-V^{\text {AERONET }}\right.}{V^{\text {AERONET }}}$} & \multirow{2}{*}{\multicolumn{2}{|c|}{$\begin{array}{l}\text { After } \\
\text { correction }\end{array}$}} \\
\hline & & & & & & & \multicolumn{2}{|c|}{$\begin{array}{l}\text { No } \\
\text { correction }\end{array}$} & & & \multicolumn{2}{|c|}{$\begin{array}{l}\text { No } \\
\text { correction }\end{array}$} & & \\
\hline Alta Floresta & $-09^{\circ} 52^{\prime} 15^{\prime \prime}$ & $-56^{\circ} 06^{\prime} 14^{\prime \prime}$ & 277 & $\mathrm{D}, \mathrm{BB} / \mathrm{R}$ & $0.42 \pm 0.59$ & $1.5 \pm 0.4$ & -16.3 & 27.3 & -10.2 & 24.7 & -46.6 & 19.5 & -11.5 & 25.4 \\
\hline Bahrain & $26^{\circ} 12^{\prime} 28^{\prime \prime}$ & $50^{\circ} 36^{\prime} 32^{\prime \prime}$ & 25 & $\mathrm{D} / \mathrm{U}$ & $0.38 \pm 0.19$ & $0.7 \pm 0.4$ & -19.6 & 22.2 & -7.0 & 34.3 & -44.1 & 13.7 & -3.5 & 21.5 \\
\hline Blida & $36^{\circ} 30^{\prime} 28^{\prime \prime}$ & $02^{\circ} 52^{\prime} 51^{\prime \prime}$ & 230 & $\mathrm{D}, \mathrm{P} / \mathrm{U}$ & $0.23 \pm 0.16$ & 1. \pm 0.4 & -8.9 & 27.0 & 6.7 & 31.4 & -42.3 & 18.1 & 5.6 & 32.0 \\
\hline Buenos Aires & $-34^{\circ} 34^{\prime} 01^{\prime \prime}$ & $-58^{\circ} 30^{\prime} 00^{\prime \prime}$ & 10 & $\mathrm{P} / \mathrm{U}$ & $0.12 \pm 0.10$ & $1.3 \pm 0.4$ & -12.3 & 55.0 & 10.0 & 50.1 & -45.3 & 34.2 & 0.9 & 38.0 \\
\hline Dalanzadgad & $43^{\circ} 34^{\prime} 37^{\prime \prime}$ & $104^{\circ} 25^{\prime} 08^{\prime \prime}$ & 1470 & $\mathrm{D}, \mathrm{BB} / \mathrm{R}$ & $0.15 \pm 0.18$ & $1.1 \pm 0.5$ & -10.0 & 42.6 & 6.9 & 48.3 & -40.6 & 27.7 & 7.5 & 37.3 \\
\hline Eilat & $29^{\circ} 30^{\prime} 10^{\prime \prime}$ & $34^{\circ} 55^{\prime} 01^{\prime \prime}$ & 15 & $\mathrm{D} / \mathrm{U}$ & $0.24 \pm 0.14$ & $0.9 \pm 0.4$ & -3.9 & 27.5 & 0.1 & 35.1 & -49.0 & 14.3 & -8.0 & 21.2 \\
\hline Granada & $37^{\circ} 09^{\prime} 50^{\prime \prime}$ & $-03^{\circ} 36^{\prime} 18^{\prime \prime}$ & 680 & $\mathrm{P}, \mathrm{D} / \mathrm{U}$ & $0.18 \pm 0.11$ & $1.1 \pm 0.5$ & -3.1 & 29.9 & 8.7 & 33.2 & -50.1 & 14.8 & -10.3 & 26.7 \\
\hline Gwangju & $35^{\circ} 13^{\prime} 40^{\prime \prime}$ & $126^{\circ} 50^{\prime} 34^{\prime \prime}$ & 52 & $\mathrm{P} / \mathrm{U}$ & $0.45 \pm 0.32$ & $1.3 \pm 0.3$ & -2.4 & 26.2 & 6.5 & 32.6 & -32.9 & 16.5 & 10.0 & 33.2 \\
\hline Ispra & $45^{\circ} 48^{\prime} 10^{\prime \prime}$ & $08^{\circ} 37^{\prime} 37^{\prime \prime}$ & 235 & $\mathrm{P} / \mathrm{U}$ & $0.32 \pm 0.28$ & $1.6 \pm 0.3$ & 7.3 & 27.3 & 7.7 & 32.1 & -33.4 & 17.8 & 4.1 & 32.3 \\
\hline Mexico City & $19^{\circ} 20^{\prime} 02^{\prime \prime}$ & $-99^{\circ} 10^{\prime} 55^{\prime \prime}$ & 2268 & $\mathrm{P} / \mathrm{U}$ & $0.40 \pm 0.24$ & $1.6 \pm 0.2$ & -5.4 & 20.9 & -4.7 & 22.2 & -47.6 & 13.3 & -14.0 & 22.3 \\
\hline Moscow & $55^{\circ} 42^{\prime} 00^{\prime \prime}$ & $37^{\circ} 30^{\prime} 36^{\prime \prime}$ & 192 & $\mathrm{P} / \mathrm{U}$ & $0.27 \pm 0.28$ & $1.6 \pm 0.2$ & 4.1 & 29.1 & 5.7 & 36.1 & -36.4 & 26.6 & 8.6 & 34.1 \\
\hline Paris & $48^{\circ} 52^{\prime} 01^{\prime \prime}$ & $02^{\circ} 19^{\prime} 58^{\prime \prime}$ & 50 & $\mathrm{P} / \mathrm{U}$ & $0.24 \pm 0.15$ & $1.4 \pm 0.3$ & 15.9 & 24.3 & 12.0 & 30.2 & -40.2 & 15.5 & -1.6 & 25.3 \\
\hline Phimai & $15^{\circ} 10^{\prime} 55^{\prime \prime}$ & $102^{\circ} 33^{\prime} 50^{\prime \prime}$ & 220 & $\mathrm{P}, \mathrm{BB} / \mathrm{U}$ & $0.55 \pm 0.33$ & $1.5 \pm 0.2$ & -9.1 & 19.7 & -10.7 & 18.9 & -38.5 & 13.1 & -5.2 & 16.7 \\
\hline Río Branco & $-09^{\circ} 27^{\prime} 55^{\prime \prime}$ & $-67^{\circ} 52^{\prime} 08^{\prime \prime}$ & 212 & $\mathrm{BB}, \mathrm{P} / \mathrm{U}$ & $0.43 \pm 0.46$ & $1.7 \pm 0.2$ & 2.6 & 21.6 & 2.5 & 22.3 & -28.5 & 16.9 & 9.2 & 25.5 \\
\hline Tamanrasset & $22^{\circ} 47^{\prime} 24^{\prime \prime}$ & $05^{\circ} 31^{\prime} 48^{\prime \prime}$ & 1377 & $\mathrm{D} / \mathrm{R}$ & $0.20 \pm 0.21$ & $0.5 \pm 0.3$ & -8.5 & 29.1 & 3.1 & 30.6 & -37.2 & 15.5 & 2.9 & 21.4 \\
\hline Tenerife & $28^{\circ} 01^{\prime} 58^{\prime \prime}$ & $-16^{\circ} 37^{\prime} 58^{\prime \prime}$ & 10 & $\mathrm{D}, \mathrm{P} / \mathrm{C}$ & $0.21 \pm 0.17$ & $0.6 \pm 0.4$ & 10.4 & 34.4 & 9.5 & 38.8 & -38.8 & 17.5 & 3.3 & 26.1 \\
\hline Yakutsk & $61^{\circ} 39^{\prime} 43^{\prime \prime}$ & $129^{\circ} 22^{\prime} 01^{\prime \prime}$ & 118 & $\mathrm{P}, \mathrm{BB} / \mathrm{U}$ & $0.18 \pm 0.21$ & $1.6 \pm 0.3$ & 13.8 & 42.6 & 10.5 & 47.7 & -23.3 & 35.0 & 12.0 & 40.1 \\
\hline All Data & - & - & - & - & $0.25 \pm 0.31$ & $1.2 \pm 0.5$ & -5.9 & 39.4 & 3.9 & 32.6 & -45.3 & 24.1 & -1.5 & 32.3 \\
\hline
\end{tabular}

Table 3. Means and standard deviations of the relative differences between linear estimation (LE) and operational AERONET retrievals. For each interval of $\eta$ is given values before and after applying corrections as well as the total number of intercomparisons.

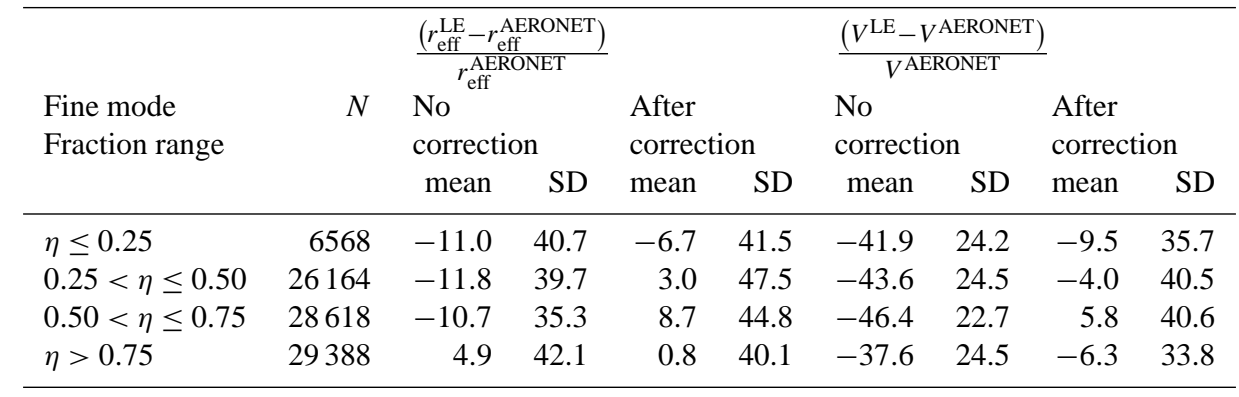

$1020 \mathrm{~nm}$. More instrument specifications can be found in (Pérez-Ramírez et al., 2008a, b, 2012b). Errors of AODs are approximately 0.02 for $\lambda<800 \mathrm{~nm}$ and 0.01 for $\lambda>800 \mathrm{~nm}$ (Pérez-Ramírez et al., 2011). The data are cloud-screened following the procedure described in (Pérez-Ramírez et al., 2012c), providing AODs every $30 \mathrm{~min}$.

The day-time values plotted for the Granada station are from LE retrievals using AODs from AERONET Level 2.0 data. The spectral range of the inversion by LE is 380$1020 \mathrm{~nm}$ for both instruments. Figure 13 shows a day-tonight time evolution of AOD(440) (AOD at $436 \mathrm{~nm}$ for nighttime), $\alpha(440-870)\left(\alpha(440-880)\right.$ for night-time), $\eta, r_{\text {eff }}$ and $V$ for the period from 20 to 30 July 2010. Table 4 shows the mean values of these parameters during each day and night, as well as the origin of 5-day backward trajectories. All LE retrievals presented are after applying the correction functions of Table 1.

Figure 13 reveals good day-to-night continuity of $\operatorname{AOD}(440)$ and of $\alpha(440-870)$, with smooth variations being observed for most of the cases, which can be mainly associated with the natural variability of aerosols. These continuities have been also observed in other works (GuerreroRascado et al., 2009; Alados-Arboledas et al., 2011; NavasGuzmán et al., 2013). The parameter $\eta$ together with the retrieved $r_{\text {eff }}$ and $V$ also reveal good day-to-night continuity. But for the star photometer measurements, more fluctuations occur due to the higher uncertainties of its measurements. Nevertheless, the current quality of the starphotometer data used here is generally sufficient to get useful estimation of day-to-night aerosol microphysical properties (Pérez-Ramírez et al., 2013). 

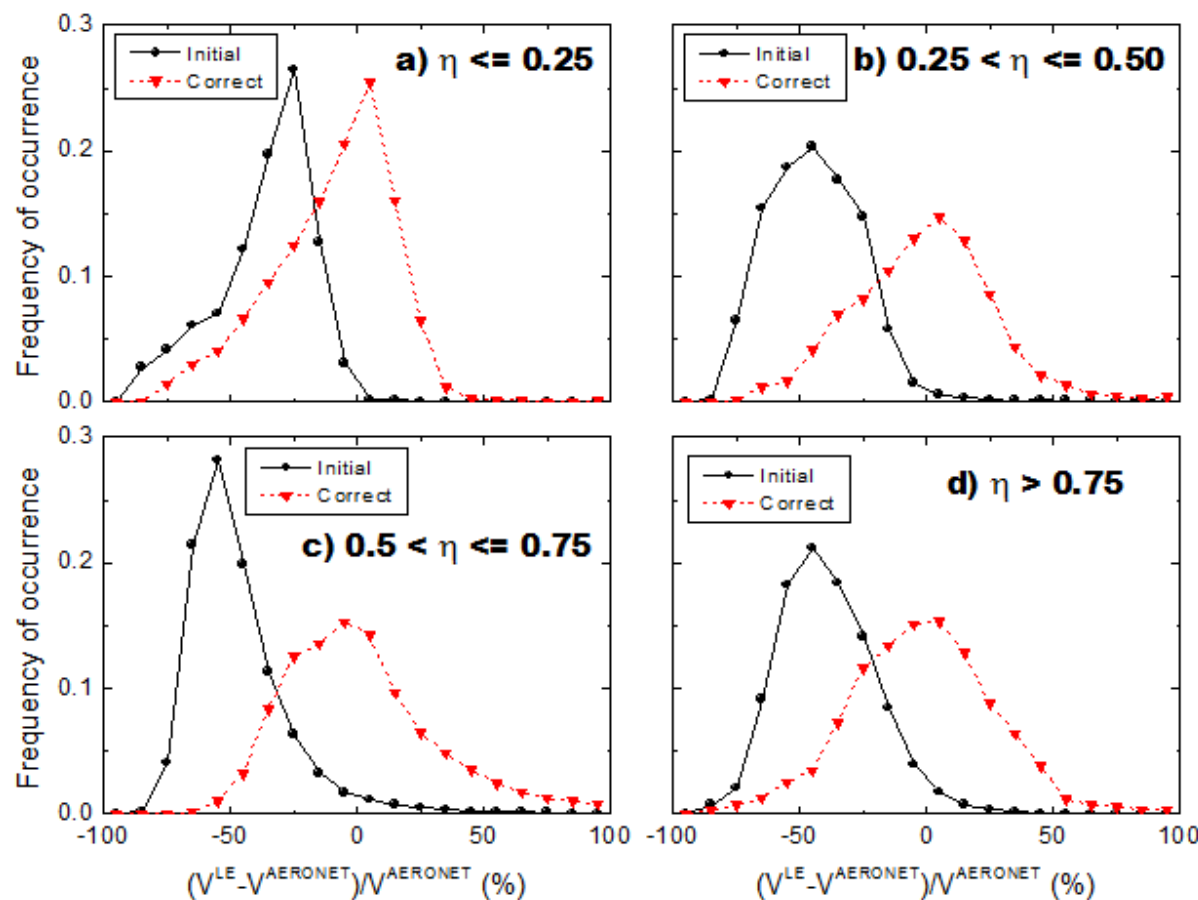

Figure 12. Frequency histograms of the relative differences of columnar volume aerosol content obtained by linear estimation $\left(V^{\mathrm{LE}}\right)$ and those obtained by AERONET ( $V^{\text {AERONET }}$ ). We used the database of $\sim 75000$ intercomparisons combining all the sites of Table 2 . Black lines correspond to data with no-correction while red lines are for data after applying correction functions.

Table 4. For the period 20-30 July using sun and star photometry measurement at Granada (Spain), mean values of day- and night-time aerosol optical depth (AOD) at $440 \mathrm{~nm}$ (436 for night-time), Angström exponent $\alpha$ computed between 440-870 nm (436-870 for nighttime), fine mode fraction to aerosol optical depth $(\eta)$, effective radius $\left(r_{\text {eff }}\right)$ and columnar volume aerosol content $(V)$. Also the air masses that reached the study area every day and night are presented. Backward trajectories of air masses were computed by HYSPLIT model at $1500 \mathrm{~m}$ a.g.1.

\begin{tabular}{llccccc}
\hline Date & Air-mass origin & AOD $(440)$ & $\alpha(440-870)$ & $\eta$ & $r_{\text {eff }}(\mu \mathrm{m})$ & $V\left(\mu \mathrm{m}^{3} \mu \mathrm{m}^{-2}\right)$ \\
\hline 20 July - Day & Local & $0.16 \pm 0.4$ & $0.9 \pm 0.2$ & $0.48 \pm 0.6$ & $0.37 \pm 0.03$ & $0.045 \pm 0.024$ \\
20/21 July - Night & Iberian Peninsula & $0.17 \pm 0.02$ & $0.9 \pm 0.1$ & $0.54 \pm 0.07$ & $0.40 \pm 0.09$ & $0.042 \pm 0.006$ \\
21 July - Day & Atlantic & $0.09 \pm 0.2$ & $0.8 \pm 0.3$ & $0.43 \pm 0.11$ & $0.38 \pm 0.05$ & $0.026 \pm 0.007$ \\
21/22 July - Night & Atlantic & $0.09 \pm 0.01$ & $1.0 \pm 0.1$ & $0.38 \pm 0.01$ & $1.67 \pm 0.08$ & $0.085 \pm 0.065$ \\
22 July - Day & Atlantic & $0.10 \pm 0.2$ & $0.6 \pm 0.1$ & $0.35 \pm 0.05$ & $0.42 \pm 0.02$ & $0.027 \pm 0.006$ \\
22/23 July - Night & Atlantic & $0.14 \pm 0.02$ & $0.5 \pm 0.2$ & $0.35 \pm 0.07$ & $0.53 \pm 0.12$ & $0.047 \pm 0.016$ \\
23 July - Day & North African & $0.21 \pm 0.4$ & $0.4 \pm 0.1$ & $0.27 \pm 0.03$ & $0.50 \pm 0.05$ & $0.080 \pm 0.030$ \\
23/24 July - Night & North African & $0.34 \pm 0.02$ & $0.5 \pm 0.1$ & $0.26 \pm 0.04$ & $0.43 \pm 0.03$ & $0.103 \pm 0.012$ \\
24 July - Day & North African & $0.54 \pm 0.13$ & $0.3 \pm 0.1$ & $0.36 \pm 0.04$ & $0.75 \pm 0.13$ & $0.360 \pm 0.110$ \\
24/25 July - Night & North African & $0.58 \pm 0.08$ & $0.5 \pm 0.1$ & $0.35 \pm 0.03$ & $0.44 \pm 0.07$ & $0.165 \pm 0.054$ \\
25 July - Day & Local & $0.27 \pm 0.12$ & $1.0 \pm 0.3$ & $0.51 \pm 0.08$ & $0.42 \pm 0.11$ & $0.112 \pm 0.105$ \\
25/26 July - Night & Iberian Peninsula & $0.16 \pm 0.03$ & $1.4 \pm 0.1$ & $0.59 \pm 0.04$ & $0.29 \pm 0.04$ & $0.035 \pm 0.008$ \\
26 July - Day & Iberian Peninsula & $0.16 \pm 0.13$ & $1.2 \pm 0.2$ & $0.58 \pm 0.07$ & $0.33 \pm 0.02$ & $0.043 \pm 0.005$ \\
26/27 July - Night & Iberian Peninsula & $0.18 \pm 0.04$ & $0.9 \pm 0.3$ & $0.46 \pm 0.07$ & $0.36 \pm 0.06$ & $0.050 \pm 0.016$ \\
27 July - Day & Iberian Peninsula & $0.28 \pm 0.02$ & $0.6 \pm 0.1$ & $0.37 \pm 0.04$ & $0.45 \pm 0.02$ & $0.097 \pm 0.029$ \\
27/28 July - Night & Mediterranean & $0.31 \pm 0.04$ & $0.5 \pm 0.1$ & $0.30 \pm 0.03$ & $0.43 \pm 0.04$ & $0.098 \pm 0.013$ \\
28 July - Day & Mediterranean & $0.29 \pm 0.02$ & $0.4 \pm 0.1$ & $0.20 \pm 0.03$ & $0.50 \pm 0.06$ & $0.124 \pm 0.040$ \\
28/29 July - Night & Mediterranean & $0.25 \pm 0.02$ & $0.5 \pm 0.1$ & $0.30 \pm 0.02$ & $0.41 \pm 0.03$ & $0.077 \pm 0.009$ \\
29 July - Day & Mediterranean & $0.25 \pm 0.02$ & $0.7 \pm 0.3$ & $0.40 \pm 0.12$ & $0.44 \pm 0.06$ & $0.093 \pm 0.030$ \\
29/30 July - Night & Mediterranean & $0.29 \pm 0.03$ & $1.1 \pm 0.2$ & $0.55 \pm 0.07$ & $0.36 \pm 0.06$ & $0.073 \pm 0.007$ \\
\hline
\end{tabular}




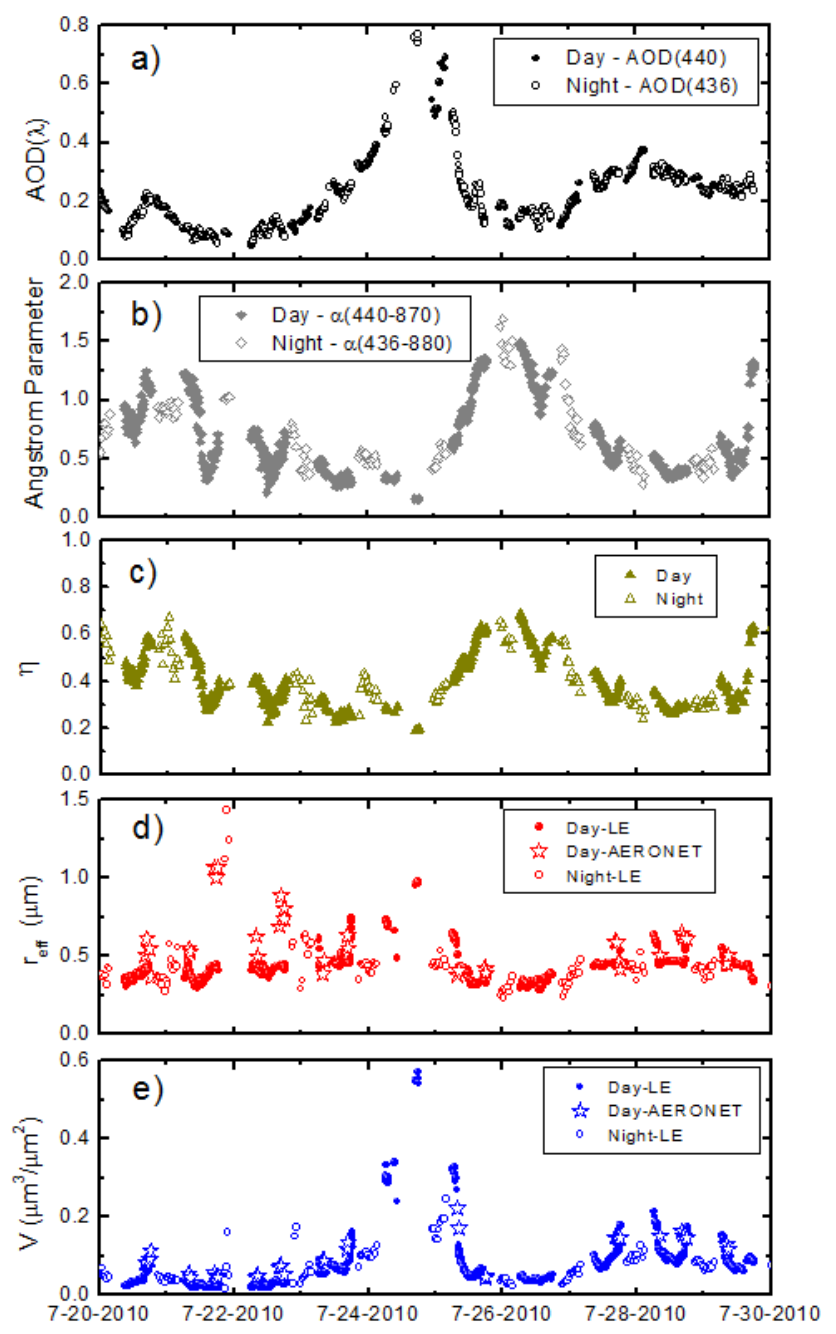

Figure 13. Day-to-night time evolutions of aerosol properties from sun-and-star photometry measurements in the city of Granada from 20 to 30 July 2010. (a) Aerosol optical depth, (b) Ångström parameter, (c) fine mode fraction, (d) effective radius, and (e) columnar volume aerosol content.

The results in Table 4 reveal that the mean values of $\operatorname{AOD}(440), \alpha(440-870), \eta, r_{\text {eff }}$ and $V$ during the daytime are close to those obtained during the night-time, with variations in aerosol parameters being observed when there are changes of the air masses that reach the study area. The air masses that had origins over the Iberian Peninsula or over the study area (e.g. 20-21 and 25-27 July) possess relatively low values of AODs $(\sim 0.15)$ and $V\left(\sim 0.10 \mu \mathrm{m}^{3} \mu^{-2}\right)$, and medium values of $\alpha(440-870)(\sim 1.0)$. The Iberian Peninsula and the study area are important sources of anthropogenic pollution (Lyamani et al., 2010, 2012), but during the summer season a significant amount of coarse particles from the ground are also injected into the atmosphere (Alados-Arboledas et al., 2003; Pérez-Ramírez et al., 2012a). This effect explains the relatively large values of $r_{\text {eff }}(0.30-0.55 \mu \mathrm{m})$ compared to those obtained in polluted areas (Dubovik et al., 2002b).
On the other hand, air masses with origins over the Atlantic Ocean (e.g. 21-23 July) are known to be very clean (e.g. Toledano et al., 2009; Lyamani et al., 2010), inducing quite low AOD(440) (mostly below 0.1). The injection of coarse particles from the ground during the summer season can explain the low values of the Angström parameter and the relatively large values of $r_{\text {eff }}(\sim 0.45-0.60 \mu \mathrm{m})$ retrieved for these air masses.

The situation is quite different, however, for North African and Mediterranean air masses that generally possess significantly higher aerosol loading. For North African air masses (e.g. 23-25 July), it is widely known from the literature that the corresponding transport of dust particles to the southeast of the Iberian Peninsula induces higher aerosol loading (e.g. Lyamani et al., 2005, 2006a; Córdoba-Jabonero et al., 2011). Particularly, during the study period of Fig. 13, AOD(440) reaches values of up to 0.75 and $V$ of up to $0.575 \mu \mathrm{m}^{3} \mu \mathrm{m}^{-2}$. Dust is characterized mainly by large amount of coarse particles, as indicated by the low values of $\alpha(440-870)(\sim 0.6-$ 0.1 ) and the large values of the $r_{\text {eff }}$ (between 0.45 and $0.98 \mu \mathrm{m}$ ), which are consistent with values reported in the literature (e.g. Lyamani et al., 2006b).

Finally, air masses originating from the Mediterranean Sea (27-30 July) can possess complex mixtures of aerosol types because this region can be a reservoir of Saharan dust particles (e.g. Meloni et al., 2007, 2008; Querol et al., 2009; Valenzuela et al., 2014) or pollutants (e.g. Pace et al., 2005; Pandolfi et al., 2011; Rodríguez et al., 2011). During the period 27-30 July, $\operatorname{AOD}(440)$ and $V$ values were, respectively, approximately 0.30 and $V \sim 0.100 \mu \mathrm{m}^{3} \mu \mathrm{m}^{-2}$. Those parameters are related to the aerosol loads and did not vary significantly in the 3-day period. However, there were variations in other aerosol properties: for the period 27-29 July the low values of $\alpha(440-870)(\sim 0.5)$ and the large values of $r_{\text {eff }}(\sim 0.50 \mu \mathrm{m})$ suggest the presence of dust particles, while from 29 July until the end of the period these properties change to $\alpha(440-870) \sim 1.0$ and $r_{\text {eff }} \sim 0.35 \mu \mathrm{m}$ suggesting the presence of fine particles associated with pollutants. Similar variability in the columnar aerosol properties in the Mediterranean have been observed in the remote island of Alboran ( $35^{\circ} 56^{\prime} 42^{\prime \prime} \mathrm{N} ; 3^{\circ} 13^{\prime} 13^{\prime \prime} \mathrm{W}$; $15 \mathrm{~m}$ a.s.l.) by Lyamani et al. (2015).

\section{Conclusions}

The applicability of the linear estimation (LE) technique for the retrieval of columnar aerosol microphysical properties such as effective radius $\left(r_{\text {eff }}\right)$ and columnar volume aerosol content $(V)$ from the spectrum of aerosol optical depth $(\operatorname{AOD}(\lambda))$ has been studied. The LE retrievals are sensitive to the constraints used, in particular to the range of inversion windows considered. To limit the "search space", information from the spectral variability of the Ångström exponent was used. Estimation of the fine mode contribution 
to the total AOD at $500 \mathrm{~nm}$ using the spectral deconvolution algorithm (SDA) (O'Neill et al., 2001a, b, 2003) was used to vary the maximum and minimum radii considered thus stabilizing the inversion. The results presented here have demonstrated the importance of adequately constraining the inversion, particularly for the cases of coarse particle predominance. The difficulty of adequately constraining the inversion for mixed mode cases was also illustrated. Finally, we have demonstrated the capabilities of LE to obtain stable retrievals with $10 \%$ noise in the input AODs, being the final uncertainties generally below $30 \%$ for $r_{\text {eff }}$ and below $40 \%$ for $V$.

For five reference AERONET locations that are characterized by different aerosol types (e.g. dust, biomass-burning, anthropogenic pollutions), the potential for high temporal resolution LE retrievals of aerosol microphysics was demonstrated. However, initially some persistent biases were found when compared with the operational AERONET retrievals: for effective radius, the agreement was quite good for predominance of fine or coarse mode, but for columnar volume aerosol content there were systematic underestimations by LE. But an important result was that the highest differences were observed for cases of mixtures of fine and coarse particles. Therefore, considering AERONET retrievals as the reference, corrections to the LE retrievals were developed to minimize the difference between the results obtained by the two retrieval techniques. These corrections were evaluated using multi-year observations from 18 other AERONET stations characterized by different aerosol types. The corrected LE retrievals worked well for scenarios where fine mode is dominant, which covers a wide range of aerosol types such as anthropogenic pollution and biomass burning. But even for predominance of the coarse mode, as in the case of dust particles, reasonable estimations of particle parameters with uncertainty below $40 \%$ were still obtained.

Although the LE approach allows the estimation of particle parameters with significantly higher temporal resolution, the number of parameters available is smaller than those obtained by the operational AERONET algorithm. Thus, the approach proposed should be considered as a supplement to the routine AERONET inversions and of interest when evaluation of high temporal evolution of effective radius and columnar volume aerosol content is needed at AERONET sites. However this technique may also be useful for simplified versions of sun photometers such as MICROTOPS, Precision Filter Radiometers (PFRs) or Multifilter Rotating Shadowband Radiometers (MFRSRs) that only provide direct-sun-irradiance measurements. The technique is also useful for nighttime observations by star or moon photometers that only provide AODs. As an example of this, we presented LE retrievals using star photometry measurements in the city of Granada (southeast of Spain) demonstrating the feasibility of the aerosol particle parameter estimation during the night-time. Continuity in day-to-night aerosol microphysical properties was observed for the different air masses reaching this area by coupling these nighttime retrievals with the daytime ones based on AERONET data. However, more variability of the star-photometer data inversion is associated with the higher uncertainties in the AODs provided by star photometer. Therefore, further improvements in star photometry are needed by limiting the effects of atmospheric turbulence in such measurements.

The proposed LE inversion approach provides bulk parameters of the total size distribution while separate retrievals of these parameters for the fine and the coarse mode separately would be desirable. A study of the feasibility of such modeseparated parameter inversion is currently in progress.

Acknowledgements. This work was supported by the NASA Atmospheric Composition Program and by the NASA Aerosols, Clouds, Ecosystems mission. Support has also been provided by the Spanish Ministry of Science and Technology through projects CGL2010-18782 and CSD2007-00067, by the Andalusian Regional Government through projects P10-RNM-6299 and P08-RNM-3568, by the EU through ACTRIS project (EU INFRA-2010-1.1.16-262254), and by the Postdoctoral Program of the University of Granada. The authors would like to express their gratitude to the NOAA Air Resources Laboratory and Naval Research Laboratory for the HYSPLIT model. We also thank the AERONET network and especially the principal investigators of the various stations used for their efforts in establishing and maintaining the AERONET sites.

Edited by: A. Kokhanovsky

\section{References}

Alados-Arboledas, L., Lyamani, H., and Olmo, F. J.: Aerosol size properties at Armilla, Granada (Spain), Q. J. Roy. Meteor. Soc., 129, 1395-1413, 2003.

Alados-Arboledas, L., Müller, D., Guerrero-Rascado, J. L., NavasGuzmán, F., Pérez-Ramírez, D., and Olmo, F. J.: Optical and microphysical properties of fresh biomass burning aerosol retrieved by Raman lidar, and star-and sun-photometry, Geophys. Res. Lett., 38, L01807, doi:10.1029/2010GL045999, 2011.

Alexandrov, M. D., Lacis, A. A., Carlson, B. E., and Cairns, B.: Characterization of atmospheric aerosols using MFRSR measurements, J. Geophys. Res., 113, D08204, doi:10.1029/2007JD009388, 2008.

Amiridis, V., Balis, D. S., Giannakaki, E., Stohl, A., Kazadzis, S., Koukouli, M. E., and Zanis, P.: Optical characteristics of biomass burning aerosols over Southeastern Europe determined from UVRaman lidar measurements, Atmos. Chem. Phys., 9, 2431-2440, doi:10.5194/acp-9-2431-2009, 2009.

Ansmann, A. and Müller, D.: Lidar and atmospheric aerosol particles, in: Lidar. Range-Resolved Optical Remote Sensing of the Atmosphere, edited by: Weitkamp, C., Springer, New York, 105141, 2005.

Baibakov, K., O’Neill, N. T., Ivanescu, L., Duck, T. J., Perro, C., Herber, A., Schulz, K.-H., and Schrems, O.: Synchronous starphotometry and lidar measurements at Eureka in High Canadian Arctic, Atmos. Meas. Tech. Discuss., 8, 2013-2065, doi:10.5194/amtd-8-2013-2015, 2015. 
Balis, D., Amiridis, V., Zerefos, C., Gerasopoulos, E., Andreae, M., Zanis, P., Kazantzidis, A., Papayannis, A., and Kazadzis, S.: Raman lidar and sunphotometric measurements of aerosol optical properties over Thessaloniki, Greece during a biomass burning episode, Atmos. Environ., 37, 4529-4538, 2003.

Barreto, A., Cuevas, E., Damiri, B., Guirado, C., Berkoff, T., Berjón, A. J., Hernández, Y., Almansa, F., and Gil, M.: A new method for nocturnal aerosol measurements with a lunar photometer prototype, Atmos. Meas. Tech., 6, 585-598, doi:10.5194/amt-6-585-2013, 2013.

Berkoff, T. A., Sorokin, M., Stone, T., Eck, T. F., Hoff, R., Welton, E. J., and Holben, B.: Nocturnal aerosol optical depth measurements with a small-aperture automated photometer using the moon as a light source, J. Atmos. Ocean. Tech., 28, 1297-1306, 2011.

Córdoba-Jabonero, C., Sorribas, M., Guerrero-Rascado, J. L., Adame, J. A., Hernández, Y., Lyamani, H., Cachorro, V., Gil, M., Alados-Arboledas, L., Cuevas, E., and de la Morena, B.: Synergetic monitoring of Saharan dust plumes and potential impact on surface: a case study of dust transport from Canary Islands to Iberian Peninsula, Atmos. Chem. Phys., 11, 3067-3091, 2011, http://www.atmos-chem-phys.net/11/3067/2011/.

De Graaf, M., Donovan, D., and Apituley, A.: Feasibility study of integral property retrieval for tropospheric aerosol from Raman lidar data using principal component analysis, Appl. Optics, 52, 2173-2186, 2013.

Donovan, D. P. and Carswell, A. I.: Principal component analysis applied to multiwavelength lidar aerosol backscatter and extinction measurements, Appl. Optics, 36, 9406-9424, 1997.

Draxler, R. R. and Rolph, G. D.: HYSPLIT (Hybrid Single-Particle Lagrangian Integrated Trajectory), model access via NOAA ARL READY website, available at: http://ready.arl.noaa.gov/ HYSPLI T.php (last access: 29 January 2015), 2003.

Dubovik, O. and King, M. D.: A flexible inversion algorithm for retrieval of aerosol optical properties from Sun and sky radiance measurements, J. Geophys. Res., 105, 20673-20696, 2000.

Dubovik, O., Smirnov, A., Holben, B. N., King, M. D., Kaufman, Y. J., Eck, T. F., and Slutsker, I.: Accuracy assessments of aerosol optical properties retrieved from Aerosol Robotic Network (AERONET) Sun and sky radiance measurements, J. Geophys. Res., 105, 9791-9806, 2000.

Dubovik, O., Holben, B., Lapyonok, T., Sinyuk, A., Mishchenko, M., Yang, P., and Slutsker, I.: Non-spherical aerosol retrieval method employing light scattering by spheroids, Geophys. Res. Lett., 29, 1415, doi:10.1029/2001GL014506, 2002a.

Dubovik, O., Holben, B., Eck, T. F., Smirnov, A., Kaufman, Y. J., King, M. D., Tanré, D., and Slutsker, I.: Variability of absorption and optical properties of key aerosol types observed in worldwide locations, J. Atmos. Sci., 59, 590-608, 2002b.

Dubovik, O., Sinyuk, A., Lapyonok, T., Holben, B. N., Mishenko, M., Yang, P., Eck, T. F., Volten, H., Munoz, O., Veihelmann, B., van der Zande, W. J., Leon, J.-F., Sorokin, M., and Slutsker, I.: Application of spheroid models to account for aerosol particle nonsphericity in remote sensing of desert dust, J. Geophys. Res., 111, D11208, doi:10.1029/2005JD006619, 2006.

Esposito, F., Serio, C., Pavese, G., Auriemma, G., and Satriano, C.: Measurements of nighttime atmospheric optical depth prelimi- nary data from mountain site in southern Italy, J. Aerosol Sci., 29, 1213-1218, 1998.

Fotiadi, A., Hatzianastassiou, N., Drakakis, E., Matsoukas, C., Pavlakis, K. G., Hatzidimitriou, D., Gerasopoulos, E., Mihalopoulos, N., and Vardavas, I.: Aerosol physical and optical properties in the Eastern Mediterranean Basin, Crete, from Aerosol Robotic Network data, Atmos. Chem. Phys., 6, 53995413, doi:10.5194/acp-6-5399-2006, 2006.

Gerasopoulos, E., Andreae, M. O., Zerefos, C. S., Andreae, T. W., Balis, D., Formenti, P., Merlet, P., Amiridis, V., and Papastefanou, C.: Climatological aspects of aerosol optical properties in Northern Greece, Atmos. Chem. Phys., 3, 2025-2041, doi:10.5194/acp-3-2025-2003, 2003.

Gerasopoulos, E., Amiridis, V., Kazadzis, S., Kokkalis, P., Eleftheratos, K., Andreae, M. O., Andreae, T. W., El-Askary, H., and Zerefos, C. S.: Three-year ground based measurements of aerosol optical depth over the Eastern Mediterranean: the urban environment of Athens, Atmos. Chem. Phys., 11, 2145-2159, doi:10.5194/acp-11-2145-2011, 2011.

Guerrero-Rascado, J. L., Olmo, F. J., Avilés-Rodríguez, I., NavasGuzmán, F., Pérez-Ramírez, D., Lyamani, H., and Alados Arboledas, L.: Extreme Saharan dust event over the southern Iberian Peninsula in september 2007: active and passive remote sensing from surface and satellite, Atmos. Chem. Phys., 9, 84538469, doi:10.5194/acp-9-8453-2009, 2009.

Herber, A., Thomason, L. W., Gernandt, H., Leiterer, U., Nagel, D., Schulz, K.-H., Kaptur, K., Albrecht, A., and Notholt, J.: Continuous day and night aerosol optical depth observations in the Arctic between 1991 and 1999, J. Geophys. Res., 107, doi:10.1029/2001JD000536, 2002.

Holben, B., Eck, T. F., Slutsker, I., Tanré, D., Buis, J. P., Setzer, A., Vermote, E., Reagan, J. A., Kaufman, Y. J., Nakajima, T., Lavenu, F., Jankowiak, I., and Smirnov, A.: AERONET - a federated instrument network and data archive for aerosol characterization, Remote Sens. Environ., 66, 1-16, 1998.

Horvath, H., Gunter, R. L., and Wilkison, S. W.: Determintation of the coarse mode of the atmospheric aerosol using data from a forward-scattering spectrometer probe, Aerosol Sci. Tech., 12, 964-980, 1990.

King, M. D., Byrne, D. M., Herman, B. M., and Reagan, J. A.: Aerosol size distributions obtained by inversion of spectral optical depth measurements, J. Atmos. Sci., 35, 2153-2167, 1978.

Kazadzis, S., Veselovskii, I., Amiridis, V., Gröbner, J., Suvorina, A., Nyeki, S., Gerasopoulos, E., Kouremeti, N., Taylor, M., Tsekeri, A., and Wehrli, C.: Aerosol microphysical retrievals from precision filter radiometer direct solar radiation measurements and comparison with AERONET, Atmos. Meas. Tech., 7, 2013 2025, doi:10.5194/amt-7-2013-2014, 2014.

Lyamani, H., Olmo, F. J., and Alados-Arboledas, L.: Saharan dust outbreakover southeastern Spain as detected by sun photometer, Atmos. Environ., 39, 7276-7284, 2005.

Lyamani, H., Olmo, F. J., Alcántara, A., and Alados-Arboledas, L.: Atmospheric aerosols during the 2003 heat wave in southeastern Spain I: Spectral optical depth, Atmos. Environ., 40, 6453-6464, 2006a.

Lyamani, H., Olmo, F. J., Alcántara, A., and Alados-Arboledas, L.: Atmospheric aerosols during the 2003 heat wave in southeastern Spain II: Microphysical columnar properties and radiative forcing, Atmos. Environ., 40, 6465-6476, 2006b. 
Lyamani, H., Olmo, F. J., and Alados-Arboledas, L.: Physical and optical properties of aerosols over an urban location in Spain: seasonal and diurnal variability, Atmos. Chem. Phys., 10, 239254, doi:10.5194/acp-10-239-2010, 2010.

Lyamani, H., Fernández-Gálvez, J., Pérez-Ramírez, D., Valenzuela, A., Antón, M., Alados, I., Titos, G., Olmo, F. J., and Alados-Arboledas, L.: Aerosol properties over two urban sites in South Spain during an extended stagnation episode in winter season, Atmos. Environ., 62, 424-432, 2012.

Lyamani, H., Valenzuela, A., Perez-Ramirez, D., Toledano, C., Granados-Muñoz, M. J., Olmo, F. J., and Alados-Arboledas, L.: Aerosol properties over the western Mediterranean basin: temporal and spatial variability, Atmos. Chem. Phys., 15, 2473-2486, doi:10.5194/acp-15-2473-2015, 2015.

Meloni, D., di Sarra, A., Biavati, G., DeLuisi, J. J., Monteleone, F., Pace, G., Piacentino, S., and Sferlazzo, D. M.: Seasonal behavior of Saharan dust events at the Mediterranean island of Lampedusa in the period 1999-2005, Atmos. Environ., 41, 3041-3056, 2007.

Meloni, D., di Sarra, A., Monteleone, F., Pace, G., Piacentino, S., and Sferlazzo, D. M.: Seasonal transport patterns of intense Saharan dust events at the Mediterranean island of Lampedusa, Atmos. Res., 88, 134-148, 2008.

Mischenko, M. I., Travis, L. D., Kahn, R. A., and West, R. A. Modeling Phase Functions for dustlike tropospheric aerosols using a shape mixture of randomly oriented polydisperse spheroids, J. Geophys. Res., 102, 16831-16847, 1997.

Müller, D., Wandinger, U., and Ansmann, A.: Microphysical particle parameters from extinction and backscatter lidar data by inversion with regularization: theory, Appl. Optics, 38, 2346-2357, 1999a.

Müller, D., Wandinger, U., and Ansmann, A.: Microphysical particle parameters from extinction and backscatter lidar data by inversion with regularization: simulation, Appl. Optics, 38, 23582368, 1999b.

Nakajima, T., Tonna, G., Rao, R., Boi, P., Kaufman, Y., and Holben, B.: Use of sky brightness measurements from ground for remote sensing of particulate polydispersions, Appl. Optics, 35, 2672-2686, 1996.

Navas-Guzmán, F., Müller, D., Bravo-Aranda, J. A., GuerreroRascado, J. L., Granados-Muñoz, M. J., Pérez-Ramírez, D., Olmo, F. J., and Alados-Arboledas, L.: Eruption of the Eyjafjallajökull Volcano in spring 2010: multiwavelength Raman lidar measurements of sulphate particles in the lower troposphere, J. Geophys. Res., 118, 1804-1813, 2013.

O’Neill, N. T., Dubovik, O., and Eck, T. F.: Modified Ångström exponent for the characterization of submicrometer aerosols, Appl. Optics, 40, 2368-2375, 2001a.

O’Neill, N. T., Eck, T. F., Holben, B., Smirnov, A., and Dubovik, O.: Bimodal size distribution influences on the variation of Angstrom derivatives in spectral and optical depth space, J. Geophys. Res., 106, 9787-9806, 2001b.

O’Neill, N. T., Eck, T. F., Smirnov, A., Holben, B., and Thulasiraman, S.: Spectral discrimination of coarse and fine mode optical depth, J. Geophys. Res., 108, 4559, doi:10.1029/2002JD002975, 2003.

Olmo, F. J., Quirantes, A., Lara, V., Lyamani, H., and Alados Arboledas, L.: Aerosol optical properties assesed by an inversion method using the solar principal plane for non-spherical particles, J. Quant. Spectrosc. Ra., 109, 1504-1516, 2008.
Pace, G., Meloni, D., and di Sarra, A.: Forest fire aerosol over the Mediterranean basin during summer 2003, J. Geophys. Res., 110, D21202, doi:10.1029/2005JD005986, 2005.

Pandolfi, M., Cusack, M., Alastuey, A., and Querol, X.: Variability of aerosol optical properties in the Western Mediterranean Basin, Atmos. Chem. Phys., 11, 8189-8203, doi:10.5194/acp-11-81892011, 2011.

Papayannis, A., Balis, D., Amiridis, V., Chourdakis, G., Tsaknakis, G., Zerefos, C., Castanho, A. D. A., Nickovic, S., Kazadzis, S., and Grabowski, J.: Measurements of Saharan dust aerosols over the Eastern Mediterranean using elastic backscatter-Raman lidar, spectrophotometric and satellite observations in the frame of the EARLINET project, Atmos. Chem. Phys., 5, 2065-2079, doi:10.5194/acp-5-2065-2005, 2005.

Papayannis, A., Mamouri, R. E., Amiridis, V., Remoundaki, E., Tsaknakis, G., Kokkalis, P., Veselovskii, I., Kolgotin, A., Nenes, A., and Fountoukis, C.: Optical-microphysical properties of Saharan dust aerosols and composition relationship using a multi-wavelength Raman lidar, in situ sensors and modelling: a case study analysis, Atmos. Chem. Phys., 12, 40114032, doi:10.5194/acp-12-4011-2012, 2012.

Pérez-Ramírez, D., Aceituno, J., Ruiz, B., Olmo, F. J., and Alados Arboledas, L.: Development and calibration of a star photometer to measure the aerosol optical depth: smoke observations at a high mountain site, Atmos. Environ., 42, 2733-2738, 2008a

Pérez-Ramírez, D., Ruiz, B., Aceituno, J., Olmo, F. J., and Alados Arboledas, L.: Application of Sun/star photometry to derive the aerosol optical depth, Int. J. Remote Sens., 17-18, 5113-5132, 2008b.

Pérez-Ramírez, D., Lyamani, H., Olmo, F. J., and Alados Arboledas, L.: Improvements in star photometry for aerosol characterizations, J. Aerosol Sci., 4, 737-745, 2011.

Pérez-Ramírez, D., Lyamani, H., Olmo, F. J., Whiteman, D. N., and Alados-Arboledas, L.: Columnar aerosol properties from sunand-star photometry: statistical comparisons and day-to-night dynamic, Atmos. Chem. Phys., 12, 9719-9738, doi:10.5194/acp12-9719-2012, 2012a.

Pérez-Ramírez, D., Navas-Guzmán, F., Lyamani, H., FernándezGálvez, J., Olmo, F. J., and Alados-Arboledas, L.: Retrievals of precipitable water vapor using star photometry: assessment with Raman lidar and link to sun photometry, J. Geophys. Res., 117, D05202, doi:10.1029/2011JD016450, 2012b.

Pérez-Ramírez, D., Lyamani, H., Olmo, F. J., Whiteman, D. N., Navas-Guzmán, F., and Alados-Arboledas, L.: Cloud screening and quality control algorithm for star photometer data: assessment with lidar measurements and with all-sky images, Atmos. Meas. Tech., 5, 1585-1599, doi:10.5194/amt-5-1585-2012, 2012c.

Pérez-Ramírez, D., Lyamani, H., Olmo, F. J., and AladosArboledas, L.: Retrieval of aerosol microphysical properties by means of sun and star photometry at Granada, Spain, Int. J. Remote Sens., 34, 3607-3624, 2013.

Querol, X., Pey, J., Pandolfi, M., Alastuey, A., Cusack, M., Pérez, N., Moreno, T., Viana, M., Mihalopoulos, N., Kallos, G., and Kleanthous, S.: African dust contributions to mean ambient $\mathrm{PM}_{10}$ mass-levels across the Mediterranean Basin, Atmos. Environ., 43, 4266-4277, 2009.

Rodríguez, S., Alastuey, A., Alonso-Pérez, S., Querol, X., Cuevas, E., Abreu-Afonso, J., Viana, M., Pérez, N., Pandolfi, M., 
and de la Rosa, J.: Transport of desert dust mixed with North African industrial pollutants in the subtropical Saharan Air Layer, Atmos. Chem. Phys., 11, 6663-6685, doi:10.5194/acp11-6663-2011, 2011.

Smirnov, A., Holben, B., Eck, T. F., Dubovik, O., and Slutsker, I.: Cloud-screening and quality control algorithms for the AERONET database, Remote Sens. Environ., 73, 337-349, 2000.

Smirnov, A., Holben, B. N., Slutsker, I., Giles, D. M., McClain, C. R., Eck, T. F., Sakerin, S. M., Macke, A., Croot, P., Zibordi, G., Quinn, P. K., Sciare, J., Kinne, S., Harvey, M., Smyth, T. J., Piketh, S., Zielinski, T., Proshutinsky, A., Goes, J. I., Nelson, N. B., Larouche, P., Radionov, V. F., Goloub, P., Krishna Moorthy, K., Matarrese, R., Robertson, E. J., and Jourdin, F.: Maritime Aerosol Network as a component of Aerosol Robotic Network, J. Geophys. Res., 114, D06204, doi:10.1029/2008JD011257, 2009.

Smirnov, A., Holben, B. N., Giles, D. M., Slutsker, I., O’Neill, N. T., Eck, T. F., Macke, A., Croot, P., Courcoux, Y., Sakerin, S. M., Smyth, T. J., Zielinski, T., Zibordi, G., Goes, J. I., Harvey, M. J., Quinn, P. K., Nelson, N. B., Radionov, V. F., Duarte, C. M., Losno, R., Sciare, J., Voss, K. J., Kinne, S., Nalli, N. R., Joseph, E., Krishna Moorthy, K., Covert, D. S., Gulev, S. K., Milinevsky, G., Larouche, P., Belanger, S., Horne, E., Chin, M., Remer, L. A., Kahn, R. A., Reid, J. S., Schulz, M., Heald, C. L., Zhang, J., Lapina, K., Kleidman, R. G., Griesfeller, J., Gaitley, B. J., Tan, Q., and Diehl, T. L.: Maritime aerosol network as a component of AERONET - first results and comparison with global aerosol models and satellite retrievals, Atmos. Meas. Tech., 4, 583-597, doi:10.5194/amt-4-583-2011, 2011.

Thomason, L. W. and Osborn, M. T.: Lidar conservation parameters derived from SAGE II extinction measurements, Geophys. Res. Lett., 19, 1655-1658, 1992.

Toledano, C., Cachorro, V. E., de Frutos, A. M., Torres, B., Berjón, A., Sorribas, M., and Stone, R. S.: Airmass classification and analysis of aerosol types at El Arenosillo (Spain), J. Appl. Meteorol. Clim., 48, 962-981, 2009.
Twomey, S.: Introduction to the Mathematics of Inversion in Remote Sensing and Linear Measurements, Elsevier, New York, 1977.

Valenzuela, A., Olmo, F. J., Lyamani, H., Granados-Muñoz, M. J., Antón, M., Guerrero-Rascado, J. L., Quirantes, A., Toledano, C., Perez-Ramirez, D., and Alados-Arboledas, L.: Aerosol transporto ver the western Mediterranean basin: evidence of the contribution of fine particles to desert dust plumes over Alboran Island, J. Geophys. Res., 119, 14028-14044, doi:10.1002/2014JD022044, 2014.

Veselovskii, I., Kolgotin, A., Griaznov, V., Müller, D., Wandinger, U., and Whiteman, D. N.: Inversion with regularization for the retrieval of tropospheric aerosol parameters from multiwavelength lidar sounding, Appl. Optics, 41, 3685-3699, 2002.

Veselovskii, I., Kolgotin, A., Griaznov, V., Müller, D., Franke, K., and Whiteman, D. N.: Inversion of multiwavelength Raman lidar data for retrieval of bimodal aerosol size distribution, Appl. Optics, 43, 1180-1195, 2004.

Veselovskii, I., Dubovik, O., Kolgotin, A., Korenskiy, M., Whiteman, D. N., Allakhverdiev, K., and Huseyinoglu, F.: Linear estimation of particle bulk parameters from multi-wavelength lidar measurements, Atmos. Meas. Tech., 5, 1135-1145, doi:10.5194/amt-5-1135-2012, 2012.

Veselovskii, I., Whiteman, D. N., Korenskiy, M., Kolgotin, A., Dubovik, O., Perez-Ramirez, D., and Suvorina, A.: Retrieval of spatio-temporal distributions of particle parameters from multiwavelength lidar measurements using the linear estimation technique and comparison with AERONET, Atmos. Meas. Tech., 6, 2671-2682, doi:10.5194/amt-6-2671-2013, 2013.

Veselovskii, I., Whiteman, D. N., Korenskiy, M., Kolgotin, A., Suvorina, A., Lyapustin, A., Wang, Y., Bian, H., Kucsera, T. L., Perez-Ramirez, D., and Holben, B.: Characterization of forest fire smoke event near Washington, DC in summer 2013 with multi-wavelength lidar, Atmos. Chem. Phys., 15, 1647-1660, doi:10.5194/acp-15-1647-2015, 2015. 